\title{
AS PROPOSTAS “BOLSOLAVISTAS” PARA A EDUCAÇÃO BRASILEIRA
}

\author{
LAS PROPUESTAS “BOLSOLAVISTAS” PARA LA EDUCACIÓN BRASILEÑA
}

\section{THE “BOLSOLAVISTAS” PROPOSALS FOR BRAZILIAN EDUCATION}

DOI: https://doi.org/10.9771/gmed.v13i3.46781

\author{
Lucas Carneiro Costa ${ }^{1}$ \\ Caroline Duailibi Felício ${ }^{2}$ \\ Francis Dávila Souza Costa ${ }^{3}$
}

Débora Rezende do Carmo Azevedo ${ }^{4}$

\begin{abstract}
Resumo: O presente trabalho propõe-se a investigar as propostas conservadoras "bolsolavistas" para a educação brasileira. Pretende-se discorrer sobre a concepção de educação e de escola que esse movimento mobiliza e nutre, em que fundamento tais as propostas foram construídas, além de posicionar sobre quais são os limites e as possibilidades dessas concepções. Escolhemos realizar uma pesquisa qualitativa. Utilizamos como método a pesquisa documental e a pesquisa bibliográfica. Foi feito um mapeamento da produção científica publicada a partir do ano de 2016 no site Google Scholar. Com a análise dos dados coletados, identificamos quatro propostas que se sobressaem: Escola sem Partido; homeschooling; o combate à "ideologia de gênero"; e escolas cívico-militares.
\end{abstract}

Palavras-chave: Bolsolavismo. Educação no governo Bolsonaro. Educação e ideologia. Olavo de Carvalho. Jair Bolsonaro.

Resumen: El presente trabajo propone investigar las propuestas conservadoras "bolsolavistas" para la educación brasileña. Se pretende discutir la concepción de educación y escuela que este movimiento moviliza y nutre, sobre qué base se construyeron tales propuestas, además de posicionarse sobre cuáles son los límites y posibilidades de estas concepciones. Optamos por realizar una investigación cualitativa. Utilizamos la investigación documental y bibliográfica como método. Se realizó un mapeo de la producción científica publicada a partir del año 2016 en el sitio web de Google Scholar. Con el análisis de los datos recolectados, identificamos cuatro propuestas que se destacan: Escuela sin Partido; educación en el hogar; combatir la "ideología de género"; y escuelas cívico-militares.

Palabras clave: Bolsolavismo. Educación en el gobierno de Bolsonaro. Educación e ideología. Olavo de Carvalho. Jair Bolsonaro.

Abstract: This work proposes to investigate the conservative "bolsolavistas" proposals for Brazilian education. It's intended to discuss the concept of education and school that this movement mobilizes and nourishes, on what basis such proposals were they are built, in addition to positioning on what are the limits and possibilities of these conceptions. To answer the questions presented, we chose to conduct qualitative research. We use documentary and bibliographic research as a method. A mapping of the scientific production published from the year 2016 on the Google Scholar website was made. With the analysis of the collected data, we identified four proposals that stand out: School Without Party (lit. transl.); homeschooling; combating "gender ideology"; and civic-military schools.

Keywords: Bolsolavismo. Education in the Bolsonaro government. Education and ideology. Olavo de Carvalho. Jair Bolsonaro. 


\section{Introdução}

O presente trabalho propõe-se a investigar e apresentar as propostas conservadoras bolsolavistas para a educação brasileira. Entendemos que a escola no Brasil passa por um momento de transição e de desconstrução (ou reconstrução). Recentemente, vários grupos e movimentos políticos elaboram, incorporam e buscam inserir na escola as suas teorias, práticas ou ideias. A escola tem-se tornado um campo de batalha onde ocorre de forma mais intensa o embate entre progressismo e conservadorismo. O momento político, social e econômico do país está bastante polarizado entre essas duas vertentes. (BRUGNAGO; CHAIA, 2014).

$\mathrm{Na}$ atual conjuntura globalizante, a educação e o trabalho docente estão sendo reconfigurados. (BARRETO, 2004). A marca do ensino ainda é o tecnicismo, o currículo tem-se adaptado às mudanças dos paradigmas econômicos, a tecnologia está cada vez mais presente nas instituições privadas e muitos teóricos questionam se a escola será substituída por práticas educacionais à distância, por modalidades como o homeschooling etc. (CHAVES, 1998). Porém, parece-nos que essa mudança da escola no Brasil vem acrescida de um debate político agressivo.

A polarização política entre esquerda e direita cresce desde os movimentos populares de junho de 2013. Esses grupos enxergam na escola tanto uma necessidade para criar sujeitos críticos quanto um lugar onde se disseminam práticas e ideologias imorais. Com essas visões, tais grupos buscam formatar a escola de acordo com seu pensamento. Surgem diversos projetos com este objetivo e a proposta do movimento "Escola sem Partido" é um exemplo. (MACEDO, 2017). Por essa razão, dissemos anteriormente que, por mais que a escola esteja em mudança, no Brasil, essa mudança vem envolvida da polarização. O que queremos dizer é que os ideólogos e grupos de poder querem fazer da escola uma "fábrica de mudança de pensamentos". Para Michel Foucault, por exemplo, a escola é uma das "instituições de sequestro", como o hospital, o quartel e a prisão. "São aquelas instituições que retiram compulsoriamente os indivíduos do espaço familiar ou social mais amplo e os internam, durante um período longo, para moldar suas condutas, disciplinar seus comportamentos e formatar aquilo que pensam". (VEIGA-NETO, 2003, p. 3).

As propostas conservadoras para a educação e para a escola brasileira são demasiadas "híbridas" e "confusas". Basicamente, o propósito é substituir as ideias progressistas que, segundo eles, estão enraizadas na escola. Todavia, como proposição, não se tem algo concreto: fala-se em militarização das escolas ao mesmo tempo em que se fala em homeschooling. Também, fala-se em Escola sem Partido ao mesmo tempo em que se fala sobre ensino confessional com aulas de ética e pensamento religioso. Soma-se tudo isso ao fato de que hoje o país é governado por um movimento ideológico conservador. Quem está na Presidência da República possui um projeto educacional próprio para o país - e isso em todas as áreas e pastas, como Segurança e Justiça, Relações Exteriores e Direitos Humanos. (FALAK, 2018). Utilizaremos o termo "bolsolavismo" para denominar esse movimento. O termo é a junção do sobrenome "Bolsonaro" e o termo "Olavismo", referindo-se, respectivamente, ao presidente atual do Brasil e ao ideário defendido pelo escritor, jornalista e filósofo Olavo de Carvalho. 
É importante esclarecer que o termo não é uma invenção nossa. A palavra “bolsolavismo” já está presente em trabalhos acadêmicos e designam o mesmo sentido que demos. Um desses trabalhos, "Uma Janela no Tempo: a ascensão do Bolsonarismo no Brasil”, artigo científico escrito por Fernanda Rios Petrarca, traz informações sobre como esse ideário foi construído:

No meio político os alunos a darem grande projeção às ideias de Olavo foram os três filhos mais velhos do presidente Jair Bolsonaro: Flávio Bolsonaro (senador), Eduardo Bolsonaro (deputado federal) e Carlos Bolsonaro (vereador pelo município do Rio de Janeiro). A integração entre o olavismo e a família Bolsonaro deu origem ao que boa parte dos analistas chamam de "bolsolavismo", representado pela intensa articulação com a direita internacional. Essa articulação ampliou espaço de atuação no governo com nomeações para diversos setores tais como: o setor das relações internacionais, na figura do Ministro das Relações Exteriores Ernesto Araújo, é aquele que mais associado está ao olavismo. Formam o seu time o olavista Filipe Martins, assessor especial da Presidência da República para assuntos internacionais. [...] Destacam-se também os assessores pessoais do gabinete do Presidente, portanto diretamente vinculado a ele, e associados aos filhos de Bolsonaro. Esse grupo de assessores, liderado por Carlos Bolsonaro e orientado por Olavo de Carvalho, deu origem ao que se designou chamar de "gabinete do ódio" ou "gabinete ideológico". Através deste gabinete, tais assessores não só orientam o presidente como comandam também várias páginas nas redes sociais [...] cujo objetivo é propagar uma campanha de intensa polarização e agressão aos adversários produzindo conteúdo especialmente para sua base eleitoral. (2021, p. 366-367).

Outro trabalho acadêmico que traz o termo bolsolavismo é da área da psicologia (a tese de doutorado "Sobre a violência no Brasil: questões e problemas para o direito e a psicologia", de Fabio Henrique Araújo Martins). Porém, o comentário é restrito a explicar o conceito dentro do cenário político brasileiro. Para o autor, "bolsolavismo" é a ala ideológica do governo representada por Ernesto de Araújo e o próprio Olavo de Carvalho. Junto com outros “4 Bs” (que são bala, boi, bíblia, bancos), sintetizam as forças políticas que atualmente controlam o Estado no Brasil (MARTINS, 2020).

Olavo de Carvalho e Jair Bolsonaro atuam em conjunto. O primeiro é o dono e criador da "teoria" que organiza atualmente o conservadorismo brasileiro. Sua obra e ideias influenciaram radicalmente os movimentos da direita política. Já Bolsonaro é quem mantém a ação política, transportando o conteúdo teórico olavista para a prática. Explicaremos a relação entre ambos adiante, mas no momento é importante citar que ambos acreditam que estamos em uma guerra cultural.

De um lado, estão eles - conservadores que lutam pela preservação da família, das instituições, dos bons costumes e da liberdade (de expressão, de comércio, entre outras). Do outro lado, conforme apregoam, está o marxismo cultural, grupo composto por setores da sociedade que quer "destruir" a civilização ocidental para implantar o socialismo. Bolsolavistas acreditam que todos os males da cultura feminismo, ação afirmativa, liberação sexual, direitos LGBTQ, decadência da educação tradicional e ambientalismo - são responsabilidade do marxismo cultural, criado pela Escola de Frankfurt. Os adeptos do marxismo cultural são acusados de ensinar sexo e homossexualidade às crianças, promover a destruição da família, controlar os meios de comunicação e promover o engodo de massas, esvaziar as igrejas e incentivar o consumo de bebidas (COSTA, 2020, p. 40).

Bolsonaro, às vésperas da posse como presidente, prometeu "combater o lixo marxista que se instalou nas instituições de ensino". Uma das falas mais recorrentes dos membros do governo e de seus apoiadores tem sido a de que a vitória eleitoral de Bolsonaro teria significado a derrota do "marxismo cultural", inspiração teórica dos governos de FHC, 
Lula e Dilma. Segundo o Ministro das Relações Exteriores, Ernesto Araújo, em um artigo publicado logo após a posse do governo, "o marxismo cultural governou por dentro de um sistema aparentemente liberal e democrático, construído por meio de corrupção, intimidação e controle de pensamento". Ricardo Vélez Rodríguez, na sua posse como Ministro da Educação, afirmou que o "marxismo cultural é uma coisa que faz mal para a saúde. A saúde da mente, do corpo e da alma". (SILVA, 2020, p. 77).

Todas as ações do governo Bolsonaro para a educação visam a combater o ideário progressista. Sendo assim, no intuito de compreender melhor o contexto atual da escola, levantamos as seguintes questões: existem propostas educacionais do grupo político que está no poder? Se sim, quais são elas? Qual é a concepção de educação e de escola que eles mobilizam e nutrem? Quais são os limites e as possibilidades dessas concepções? Em que fundamentos elas foram construídas? Para responder às questões apresentadas e atingir nossos objetivos, escolhemos realizar uma pesquisa qualitativa. Utilizamos como método a pesquisa documental e a pesquisa bibliográfica. A partir da análise dos dados coletados, identificamos quatro propostas que se sobressaem: Escola sem Partido; homeschooling; o combate à "ideologia de gênero"; e escolas cívico-militares.

\section{Metodologia}

Para responder às questões apresentadas na introdução e atingir nossos objetivos, escolhemos realizar uma pesquisa qualitativa (FLICK, 2009) documental e bibliográfica (SILVA; MERCADO, 2015) que se amparou na abordagem da revisão sistemática de literatura. Essa técnica de pesquisa consiste num método de estudo em que se analisa de forma sistêmica vários trabalhos, de gêneros e campos do conhecimento distintos, sobre um determinado tema. A revisão sistemática de literatura pode promover um levantamento de estudos realizados a partir de diferentes contextos e sujeitos (RAMOS et al., 2014). Foi feito um mapeamento da produção científica com foco na que foi publicada a partir do ano de 2016 no site Google Scholar, visando a obter dados e informações sobre as propostas bolsolavistas para a educação. Escolhemos o ano de 2016 porque naquele ano ocorreu o impeachment da presidente(a) Dilma Rousseff e coincidiu com o aumento de popularidade de discursos conservadores. E para complementar a pesquisa de forma geral, procuramos outros conteúdos, como livros, artigos publicados em anais de congresso, capítulos de livros, artigos gerais e reportagens jornalísticas.

Os critérios para a escolha dos textos foram: quantidade de citações dos trabalhos; qualidade do referencial teórico; apresentação de contribuições inéditas para o debate público; quando reportagem jornalística, sua relevância; além de materiais que sintetizassem bem o conteúdo que abordamos. A plataforma Google Scholar foi utilizada por manter em suas bases conteúdos confiáveis, técnicos, apurados, revistos e científicos. Além disso, durante o percurso acadêmico da graduação, essa mesma plataforma nos é apresentada como um excelente mecanismo para efetuar pesquisas. Em relação às reportagens jornalísticas, foi também por causa da contemporaneidade do governo e da ausência de produções acadêmicas que precisamos recorrer a esse gênero textual. Demos preferência para a mídia tradicional. Em alguns momentos, todavia, foi preciso recorrer a alguns sites específicos, como o site pessoal do escritor Olavo de Carvalho, que contém dados importantes sobre a sua produção, currículo e biografia. 
O objetivo geral deste trabalho é apresentar as propostas bolsolavistas para a educação de forma interligada e conjunta, pois acreditamos que possuem a mesma natureza e intencionalidade. Mas, cabe perguntar: de qual lugar surgem as propostas bolsolavistas para a educação? Onde é possível verificar que elas existem e quais são? Ora, é possível verificar tais propostas e saber quais são por meio: das declarações oficiais do governo Bolsonaro; de suas promessas de campanha; das ideias defendidas publicamente por seus apoiadores mais notórios; além dos projetos de lei, propostos ou aprovados, oriundos de instituições públicas ou parlamentares que possuem a mesma agenda ideológica conservadora.

Na Proposta de Plano de Governo apresentada pelo candidato Jair Bolsonaro no ano de 2018, a educação não é extensamente trabalhada. Apesar disso, o documento revela as intenções e propósitos para essa pauta: (1) a educação é apresentada como prioridade junto à segurança e à saúde (TSE, p. 10); (2) desejase dar um salto de qualidade na educação, mas com ênfase na infantil, básica e técnica, sem doutrinar (TSE, p. 22); (3) as Forças Armadas são invocadas no processo de atendimento da saúde e da educação da população (TSE, p. 34); (4) diz-se que o conteúdo e método de ensino precisam ser mudados: "mais matemática, ciências e português, sem doutrinação e sexualização precoce” (TSE, p. 41); (5) propõe-se, além de mudar o método de gestão, na educação revisar e modernizar o conteúdo (currículo escolar), que inclui a alfabetização, expurgando a ideologia de Paulo Freire, mudando a Base Nacional Comum Curricular (BNCC), impedindo a aprovação automática e a própria questão de disciplina dentro das escolas (TSE, p. 46); (6) propõe-se a educação à distância ao afirmar que essa "deveria ser vista como um importante instrumento e não vetada de forma dogmática” ou, também, "deve ser considerada como alternativa para as áreas rurais" (TSE, p. 46); (7) nas considerações finais, coloca-se que é objetivo do governo "brigar para que os jovens tenham um futuro e [...] não fiquem desamparados por [...] uma educação aparelhada ideologicamente" (TSE, p. 80).

Quando se fala em doutrinação, ou quando é escrito que o objetivo é expurgar a ideologia de Paulo Freire, rememora-se o projeto Escola sem Partido. Quando se fala em sexualização precoce, rememora-se o combate à "ideologia de gênero". Ao dizer que se deve impedir a indisciplina nas escolas, ou que as Forças Armadas devem ser invocadas no processo de atendimento educacional da população, rememora-se o projeto das escolas cívico-militares. Por fim, quando se traz a questão do ensino à distância, é possível relacionar a prática com o homeschooling. Vale lembrar que para essas duas últimas propostas, escolas cívico-militares e homeschooling, o governo Bolsonaro já produziu projetos de lei, decretos e portarias que defendem o seu conteúdo.

Olavo de Carvalho, por outro lado, é um crítico do Escola sem Partido, mas não se posiciona de maneira contrária à proposta ou sua natureza. Ele diz que o problema é muito centrado em mudar a legislação, mas pouco íntimo do combate cultural. Isto é, para Olavo de Carvalho a mudança da legislação, apesar de positiva, não é suficiente para "resolver o problema da doutrinação nas escolas" em longo prazo ou de forma efetiva. Complementarmente, se posiciona favorável ao homeschooling, pois:

a pretexto de educar nossos filhos, [politiqueiros e manipuladores ideológicos] lhes impõe [por intermédio da escola] todo um sistema de deformidades mentais e morais para fazer deles idiotas criminosos à imagem e semelhança de nossos governantes. [...] Carlos 
Artexes Simões não percebe a monstruosidade comunofascista que profere ao declarar que "a escola ainda é a vanguarda do ponto de vista do conhecimento necessário para a construção de um Estado republicano". [...] Não sabe ele que tipo de socialização nossas crianças encontram nas escolas públicas? Não sabe que estas são fábricas de desajustados, de delinquentes, de criminosos? Não sabe que, em nome da socialização, as condutas piores e mais violentas são ali incentivadas pelo próprio governo que ele representa? Não sabe que agredir professores, destruir o patrimônio das escolas, consumir drogas, entregar-se a obscenidades em público, são atos considerados normais e até desejáveis nessas instituições do inferno? Não sabe ele que há um crescimento proporcional direto da criminalidade infanto-juvenil à medida que se amplia a escolarização? (CARVALHO, 2019).

Ao ler esse trecho, pode parecer que a preocupação de Olavo de Carvalho não é, em sua essência, ideológica, mas sim em relação à qualidade das escolas. No entanto, vale lembrar que ele acredita que "a criminalidade nas escolas" só acontece por conta da doutrinação de esquerda. Para ele, os "manipuladores ideológicos" visam a fomentar a criminalidade para que, através dela, a revolução socialista aconteça:

Logo após a tomada do poder pelos comunistas na Rússia, a política oficial era fomentar o sexo livre, criando assim uma geração de jovens sem família para incentivar a criminalidade juvenil e liquidar pela confusão o que restasse da "ordem burguesa" [...] a URSS começou a treinar agentes para que se infiltrassem nas então incipientes redes de tráfico de drogas - especialmente na América Latina - e as dominassem por dentro, criando uma futura fonte local de subsídios para o movimento revolucionário, que estava saindo caro demais para o bolso soviético. Essa foi a origem remota das Farc, Forças Armadas Revolucionárias da Colômbia, que hoje dominam o narcotráfico no continente. (CARVALHO, 2013, p. 505-506).

Ao ter contato com outros artigos de sua autoria, fica claro que ele acredita que a educação é dominada por marxistas:

A partir dos anos 1980, a elite esquerdista tomou posse da educação pública, aí introduzindo o sistema de alfabetização "socioconstrutivista", concebido por pedagogos esquerdistas como Emilia Ferrero, Lev Vigotsky e Paulo Freire para implantar na mente infantil as estruturas cognitivas aptas a preparar o desenvolvimento mais ou menos espontâneo de uma cosmovisão socialista, praticamente sem necessidade de “doutrinação" explícita. (CARVALHO, 2013, p. 350).

Assim, acaba se posicionando também contrário à “ideologia de gênero”. Para ele,

aplicada à educação, [a ideologia de gênero] destrói nas crianças a capacidade de distinguir entre realidade e fantasia, entre ser e parecer, e cria uma geração de pequenos imbecis que, ao chegar à universidade, não servirão para mais nada além de se divertir, bater pezinho com exigências impossíveis, e fazer uma confusão dos diabos com o pouco que tiverem conseguido aprender. (CARVALHO, 2016).

Olavo de Carvalho ainda não se declarou contrário ou favorável à proposta das escolas cívicomilitares. Mas, assim como as outras as propostas que estamos analisando, dezenas de seus seguidores mais influentes já se posicionaram a favor.

Após a escolha dos textos, foi realizada a leitura desses, seguida da elaboração do resumo com preenchimento de quadros de análise com os possíveis elementos que identificassem, para cada capítulo, as principais conceituações, acontecimentos ou descrições das propostas. Esclarecemos ainda que nossa análise foi composta, assim como o trabalho de Gonçalves (2011), por quatro fases: a) pré-análise; b) exploração do material; c) tratamento dos resultados; e d) interpretação. A pré-análise envolveu a leitura e o destaque dos elementos comuns e incomuns que apareciam nos textos. $\mathrm{Na}$ exploração do material, enfatizamos os pontos em comum dos autores, mas também destacamos alguns conflitos entre eles em relação ao tema. 
$\mathrm{Na}$ terceira fase, relacionada ao tratamento e interpretação, preenchemos fichas (que listavam os textos, seus objetivos e os elementos ressaltados), de modo a organizar todo o trabalho. Após esse procedimento, fizemos a separação das fichas por noção, acrescidas das definições dos conceitos que apareciam nos textos. $\mathrm{Na}$ última fase, selecionamos as noções mais importantes retiradas dos autores lidos, de forma a analisá-las mediante nosso referencial teórico. A análise procedeu-se da seguinte maneira: entre os textos selecionados, com o intuito de desenvolver as ideias dos autores, respeitamos a ordem cronológica dos acontecimentos, de forma a possibilitar aos leitores a compreensão da evolução da constituição das propostas bolsolavistas.

\section{Educação, escola, ideologia e o conservadorismo bolsolavista}

Em todos os aspectos da sociedade a educação está presente. Nenhuma instituição social ou indivíduo "foge" ou deixa de ter contato com ela. A educação está em todo lugar e não só na escola: nas ruas, comunidades religiosas, no trabalho etc. E todos estamos envolvidos porque aprendemos, ensinamos e ensinamos-aprendendo a todo instante. Para Brandão (1981, p.10), "a educação pode existir livre e, entre todos, pode ser uma das maneiras que as pessoas criaram para tornar comum, como saber, como ideia ou crença aquilo que é comunitário como bem, como trabalho ou como vida”. É, assim, uma fração do modo de vida. Ele ainda completa, afirmando que educação é:

[...] como outras, uma fração do modo de vida dos grupos sociais que a criam e recriam, entre tantas outras invenções de sua cultura, em sua sociedade. Formas de educação que produzem e praticam, para que elas reproduzam, entre todos os que ensinam-eaprendem, o saber que atravessa as palavras da tribo, os códigos sociais de conduta, as regras do trabalho, os segredos da arte ou da religião, do artesanato ou da tecnologia que qualquer povo precisa para reinventar, todos os dias, a vida do grupo e a de cada um de seus sujeitos, através de trocas sem fim com a natureza e entre os homens, trocas que existem dentro do mundo social onde a própria educação habita, e desde onde ajuda a explicar - às vezes a ocultar, às vezes a inculcar — de geração em geração, a necessidade da existência de sua ordem. (BRANDÃO, 1981, p. 33).

A educação é um fenômeno social. Por isso, é o ser humano que cria e que transforma, com o trabalho e a (sua) consciência, partes da natureza em invenções de sua cultura (por meio do tempo e da comunicação constante consigo e com os outros). No caso da educação, são as diversas situações, de aprender e ensinar, cotidianas e sociais, que vão conduzindo a sua mudança. Afinal, para ajustar uma criança à sua comunidade, ela precisa ser educada de acordo com os valores (que se alteram ao longo da história) da sua determinada tribo.

Para Brandão, por exemplo, "quando um povo alcança um estágio complexo de organização social e cultural, quando ele enfrenta a questão da divisão social do trabalho e, portanto, do poder, é que ele começa a viver e a pensar como problema as formas e os processos da transmissão do saber". Aliás, essa questão é facilmente comprovada. A escrita surgiu em sociedades economicamente ricas, pois os grandes proprietários (no caso, principalmente reis e governantes) precisavam registrar o que tinham. É assim, então, que surge a escola.

Mesmo em algumas sociedades primitivas, quando o trabalho que produz os bens e quando o poder que reproduz a ordem são divididos e começam a gerar hierarquias sociais, também o saber comum 
da tribo se divide. Começa-se a distribuir desigualmente e pode passar a servir ao uso político de reforçar a diferença no lugar de um saber anterior. Emergem tipos e graus de saber que correspondem desigualmente a diferentes categorias de sujeito (o rei, o sacerdote), cada um de acordo com sua posição social no sistema. É nesse cenário que surge a escola.

Escola, em si, é o ambiente onde se ensina. Porém, é mais do que isso: é uma instituição social. E o seu surgimento tem um intuito, que é cumprir as exigências sociais de formação de tipos concretos de pessoas na e para a sociedade. A educação, portanto, é prática social que produz sujeitos sociais. E essa prática acontece na escola. Esse fenômeno do surgimento da escola é um modo próprio de educar - por isso, é diferente de uma cultura para outra - mas, em todo caso, necessária à vida e à reprodução da ordem de cada tipo de sociedade, em cada momento de sua história.

A escola não é neutra nem pura. O seu próprio surgimento já é um indicativo de que ela possui um propósito. A ideia de que não existe coisa alguma de social na educação; de que, como a arte, ela é "pura" e não deve ser corrompida por interesses e controles sociais, pode ocultar o interesse político de usar a educação como uma arma de controle e dizer que ela não tem nada a ver com isso. Mas o desvendamento de que a escola é uma prática social pode ser também feito numa direção ou noutra e, tal como vimos antes, pode se dividir em ideias opostas, situadas de um lado ou de outro da questão. As armas não tinham conseguido submeter os povos inimigos de qualquer nação a não ser parcialmente. (BRANDÃO, 1981). É responsabilidade da educação, por meio da escola, institucionalizar o domínio. Todos esses processos de domínio ou consolidação de poder têm, como pano de fundo, uma ideologia.

A relação entre ideologia e educação é que, em sociedades complexas, a escola tende a refletir os fenômenos sociais que acontecem fora dela. Não necessariamente a escola reproduz ipsis litteris o que acontece na sociedade - a questão é que o ideário social permeia a forma pela qual o conteúdo (além da organização do espaço e do tempo) é ensinado na escola. Não só isso, também influencia na formação do currículo e da escolha sobre o que deve se falar e apresentar. Segundo Tomaz Tadeu da Silva (2010), currículo gira em torno da questão “o que ensinar?”. Obviamente, na escola deve-se ensinar algo. E o currículo é a "ciência" que estuda o que ensinar. Todas as discussões curriculares giram em torno desta questão - que sujeitos formar, que matérias e conteúdo repassar, o que abordar na aula, como a aula deve ser, qual o propósito de ensinar um conteúdo "x" e não "y" etc. É, em simples palavras, o planejamento, a teoria. Mesmo assim, um currículo não se constrói a esmo. É necessário escolher o que falar. Devido a esse fato: (1) o currículo está intrinsicamente ligado à escola; e (2) é entendido como espaço de disputa e um lugar onde sempre ocorrem conflitos. Os temas currículo, poder e identidade estão mutuamente interligados.

Qualquer conteúdo que se ensina na escola tem uma intenção. A prática cotidiana, a definição de tempos e espaços e toda a ritualística da escola fundamenta-se em ideologias e concepções de mundo, de ser humano e de educação. Ou seja, as práticas educativas são intencionais. A escola serve para formar cidadãos. Esses devem dominar temas relativos à vida em sociedade: os valores da democracia, a importância do trabalho, as disciplinas técnicas para o mercado, entre coisas do gênero. Portanto, todo movimento político que se dispõe a mudar a sociedade, indiretamente, possui propostas para a educação. 
Nessa altura, é importante dizer que não são todos os movimentos que se reconhecem como ideológicos. E por se considerarem assim, ausentes de ideologias específicas, creem que não possuem propostas com o intuito de mudar a sociedade. Um exemplo são os movimentos conservadores, objeto de análise deste trabalho. Michael Oakeshott, um dos principais herdeiros do conservadorismo clássico, defende que o conservadorismo

não é uma crença nem uma doutrina, mas uma forma de ser e estar. Ser conservador significa uma inclinação a pensar e a comportar-se de determinada forma; é preferir certas formas de conduta e certas condições das circunstâncias humanas a outras; é dispor-se a tomar determinadas decisões. [...] Distinguir as características gerais dessa atitude não é tarefa difícil, embora elas tenham sido constantemente confundidas. Elas resumem-se a uma propensão ao uso e gozo daquilo que se tem, em vez do desejo ou busca de outra coisa, a aprazer-se mais com o presente do que com o passado ou o futuro. [...] Assim, ser conservador é preferir o familiar ao desconhecido, preferir o tentado ao não tentado, o facto ao mistério, o real ao possível, o limitado ao ilimitado, o próximo ao distante, o suficiente ao superabundante, o conveniente ao perfeito, a felicidade presente à utópica. [...] Para além disso, ser conservador não é apenas ser avesso à mudança [...] é também a forma de nos adaptarmos às mudanças, algo que foi imposto a todos os homens. (2014, p. 4-6)

Russel Kirk, que também é um autor conservador, desenvolve uma concepção semelhante:

Não sendo nem uma religião nem uma ideologia, o conjunto de opiniões designado como conservadorismo não possui nem uma Escritura Sagrada, nem um Das Kapital, como fonte de dogmas. [...] Talvez fosse adequado, na maioria das vezes, utilizar a palavra 'conservador' mormente como adjetivo. Não existe um modelo conservador, e o conservadorismo é a negação da ideologia: é um estado de espírito, um tipo de caráter, um modo de ver a ordem civil e social. A posição chamada conservadora se sustenta em um conjunto de sentimentos, e não em um sistema de dogmas ideológicos. [...] Para a preservação de uma diversidade saudável em qualquer civilização, devem remanescer ordens e classes, diferenças na condição material e muitos tipos de desigualdade. (2014, p.102-108)

Contudo, fenômenos conservadores não se restringem a essa perspectiva definida. Ferreira e

Botelho fazem uma conceituação do conservadorismo de acordo com a perspectiva que apresentaremos:

O pensamento conservador surge e se desenvolve no contexto da moderna sociedade de classes, marcado por seu dinamismo, por suas múltiplas e sucessivas transições; como função dessa sociedade, não é um sistema fechado e pronto, mas sim um modo de pensar em contínuo processo de desenvolvimento [...]. Estruturado como reação ao Iluminismo e às grandes transformações impostas pela Revolução Francesa e pela Revolução Industrial, o conservadorismo valoriza formas de vida e de organização social passadas, cujas raízes se situam na Idade Média. É comum entre os conservadores a importância dada à religião; a valorização das associações intermediárias situadas entre o Estado e os indivíduos (família, aldeia tradicional, corporação) e a correlata crítica à centralização estatal e ao individualismo moderno; o apreço às hierarquias e a aversão ao igualitarismo em suas várias manifestações; o espectro da desorganização social visto como consequência das mudanças vividas pela sociedade ocidental. (2010, p. 11, 12).

A razão para a escolha dessa conceituação de conservadorismo se dá porque, apesar de muitos conservadores rogarem para si mesmos a posição de neutralidade e ceticismo, bem como contrários em relação a uma mudança radical e abrupta da sociedade, muitos são, na verdade, reacionários. (BRAZ, 2017). Nas ciências sociais, particularmente na ciência política, podemos definir como reacionário alguém (ou uma instituição) que advoga por um retorno a um estado (no sentido de situação) político anterior da sociedade. Reacionários creem que o período atual, a contemporaneidade, está degenerada. Assim, a melhor solução, 
para eles, é voltar ao passado. Não menos importante, vale citar que reacionário é o antônimo de revolucionário. Halimi define ambos os termos da seguinte forma:

Eram duas correntes de intelectuais que se defrontavam. De um lado, aqueles que, sob o discurso da "reforma", da "abertura", da ruptura com os "tabus", saudavam o movimento do mundo - e os avanços da esquerda, quando das eleições. Com o apoio da maioria dos meios de comunicação, estavam sempre dispostos a se mobilizar em nome de um "progresso" que incentivava as estruturas econômicas que seu pensamento único popularizara. $\mathrm{Na}$ outra corrente estavam aqueles a quem essa "modernidade" preocupava, ou repugnava, pois viam nela uma forma de regressão na organização da sociedade e na solidariedade que a costura. Eram considerados "reacionários" pelos primeiros. (HALIMI, 2003).

Situar os movimentos conservadores brasileiros como reacionários não é um juízo de valor negativo. Essa "ressalva" se dá, pois, ao analisar particularmente o fenômeno conservador brasileiro, podemos observar uma ascensão (ou até mesmo uma predominância) de discursos e movimentos cristãos, autoritários e antiacadêmicos. O bolsolavismo é o principal ramo que coaduna essa multifacetação do conservadorismo brasileiro. Mas, antes de apresentarmos sua história e contexto, é necessário detalhar quais são esses discursos e movimentos "cristãos", "autoritários" e "antiacadêmicos".

Sobre movimentos cristãos, podemos citar religiosos católicos e evangélicos que, por exemplo, posicionam-se contra a casamento civil entre pessoas do mesmo sexo ${ }^{5}$ e a descriminalização (ou legalização) do uso das drogas. A razão para a oposição a essas pautas é de natureza religiosa. Para alguns deles, o Estado não deve ser laico. Sobre grupos autoritários, podemos citar os que defendem projetos como intervenção militar (nos moldes da Ditadura Militar, 1964-1985) ${ }^{6}$, alteração do regime republicano e presidencialista para uma monarquia ${ }^{7}$ ou até mesmo o integralismo e a filosofia política de Plínio Salgado ${ }^{8}$. Não é raro, também, achar associações neonazistas nas ditas fileiras conservadoras9. Ideias antiacadêmicas (popularmente conhecidas como "teorias da conspiração") são reforçadas em alguns movimentos conservadores brasileiros. As principais e mais populares versam sobre conjuntos de estratégias e movimentos que, desenvolvidos por setores de esquerda, grupos comunistas ou países socialistas (como China, Cuba e Coréia do Norte) objetivam a destruição da cultura ocidental ou até mesmo do Brasil enquanto nação (exemplos desses grupos: marxismo cultural, Foro de São Paulo, Comissão Trilateral, Nova Ordem Mundial, entre outros). E mantendo uma visão sob influência da religião cristã, muitos conservadores reforçam ideias que se revelam anticientíficas. Figuras públicas conservadoras - membros, ministros e servidores do governo Bolsonaro, inclusive - constantemente apoiam a ideia de que: "a Terra é plana"10; "as vacinas causam autismo e são prejudiciais à saúde da população"11; "o aquecimento global não existe"12; entre outras. Vale ressaltar que as visões anticientíficas não se restringem somente às ciências naturais, mas sim a qualquer campo do conhecimento que seja acadêmico. As metodologias que sustentam a história e a filosofia (ciências humanas) são também falseadas. Para muitos conservadores brasileiros: "Stálin foi o arquiteto da Segunda Guerra Mundial”13; "o nazismo é um movimento de esquerda com origens marxistas"14; "a escravização foi benéfica para os negros africanos" ${ }^{15}$; entre diversas outras.

A origem de muitas dessas ideias é a obra e a falas públicas do escritor Olavo de Carvalho. Olavo Luiz Pimentel de Carvalho nasceu em Campinas (SP) no dia 29 de abril de 1947, sendo o segundo filho do 
Luiz Gonzaga de Carvalho, advogado, e de Nicéa Pimentel de Carvalho. É filósofo, escritor, jornalista e conferencista. Mora, desde 2005, em Richmond, no estado da Virgínia (EUA).

Segundo ele mesmo informa em seu currículo, disponível em seu website pessoal, começou a trabalhar na imprensa quando não tinha ainda 18 anos completos, na Empresa Folha da Manhã S/A, onde, nos vários jornais que a compõem, foi sucessivamente "repórter, redator copy desk, setorista credenciado no Palácio do Governo”. Em seguida, trabalhou nos jornais: “A Gazeta” como subeditor de reportagem local; na revista "Atualidades Médicas” como editor de texto; no semanário “Aqui, São Paulo” como subeditor e secretário gráfico; no "Jornal da Semana” como secretário de redação; e no "Jornal da Tarde”, d’O Estado de S. Paulo, como redator na Editoria de Política e Economia. Escreveu, ainda como colaborador, para vários outros jornais e revistas, sobre assuntos culturais. Dentre as publicações com as quais colaborou destacam-se: "Nova”, “Contexto”, "Brasil-Israel”, "Escola”, "Planeta”, “Sala de Aula”, "Quatro Rodas", "Imprensa", "Livro Aberto" - de São Paulo - e “Tribuna da Imprensa"," O Globo" e "Jornal do Brasil” do Rio de Janeiro.

Apesar de atuar como jornalista - tendo recebido o Registro de Jornalista Profissional por tempo de serviço, de acordo com a legislação da época - Olavo de Carvalho não concluiu o ensino superior. Num primeiro momento, estudou Filosofia no Conjunto de Pesquisa Filosófica (Conpefil) da PUC do Rio de Janeiro. E embora, segundo ele mesmo, tenha apresentado dois trabalhos de conclusão do curso, não chegou a graduar-se por causa da extinção da entidade logo após o falecimento de seu fundador e diretor, Pe. Stanislavs Ladusãns. Após o episódio, abdicou dos estudos universitários formais. Ainda em seu currículo, afirma que só prosseguiu dessa forma por não ter encontrado "cursos universitários de boa qualidade sobre os tópicos que eram de seu interesse". Sendo assim, estudou com professores particulares sobre diversos assuntos, de psicologia a religiões comparadas (destacam-se os nomes de Marcel van Cutsem, filólogo belga, José Khoury, filólogo libanês, e Martin Lings, filósofo britânico).

A partir de 1977, a convite de várias instituições, começou a dar conferências, palestras e cursos sobre os vários assuntos que estudava e escrevia na imprensa. Em seu currículo, é possível verificar que ministrou em várias associações, universidades, escolas, centros educacionais, entidades governamentais, institutos de pesquisa, empresas privadas, entre outras.

Carvalho participou de congressos, seminários e conferências, publicando diversos trabalhos. Também traduziu e editou obras de outros escritores, além de escrever apostilas para seus cursos (atualmente ministra em uma instituição própria - o Seminário de Filosofia - um curso de filosofia) e fazer traduções. Seus livros começaram a ser publicados no ano de 1983. Até o momento, escreveu 36 livros, dos quais o mais vendido é "O mínimo que você precisa saber para não ser um idiota”, publicado no ano de 2013 pela editora Record.

A obra e o pensamento de Carvalho são amplos e envolvem diversos campos do conhecimento: religiões comparadas, filosofia, história, política, ciências, educação, entre outros. No entanto, vale ressaltar que a opinião de Carvalho sofreu mudanças ao longo de toda a sua carreira (que, aliás, ainda prossegue nos dias de hoje). Como este trabalho não se propõe a analisar o conjunto de todos os seus escritos, nos 
limitaremos a fazer uma análise contemporânea de suas posições. Atualmente, Roxane de Carvalho, estudiosa e esposa de Olavo de Carvalho, caracteriza sua obra em duas grandes vertentes.

A primeira, principal e da qual descendem (se originam) todas as suas ideias e posicionamentos, diz que Carvalho: (1) caracteriza-se por desenvolver uma filosofia da consciência, a qual reforça a importância da consciência individual contra doutrinas que tentam suprimi-la; (2) não avalia o mundo contemporâneo como uma realização do progresso, mas como um ocaso (entrada de uma civilização na barbárie). Isso seria o resultado de um processo de fortalecimento da consciência coletiva, iniciado no século XV e que atinge seu ápice na Revolução Francesa. A relevância de instituições acadêmicas, o distanciamento de tradições, entre outros, são as razões pelas quais se acredita que estamos, enquanto civilização, em declínio ${ }^{16}$

A tônica [da obra de Carvalho] é a defesa da interioridade humana contra a tirania da autoridade coletiva, sobretudo quando escorada numa ideologia "científica". Para Olavo de Carvalho, existe um vínculo indissolúvel entre a objetividade do conhecimento e a autonomia da consciência individual, vínculo este que se perde de vista quando o critério de validade do saber é reduzido a um formulário impessoal e uniforme para uso da classe acadêmica. Acreditando que o mais sólido abrigo da consciência individual contra a alienação e a coisificação se encontra nas antigas tradições espirituais — taoísmo, judaísmo, cristianismo, islamismo - Olavo de Carvalho procura dar uma nova interpretação aos símbolos e ritos dessas tradições, fazendo deles as matrizes de uma estratégia filosófica e científica para a resolução de problemas da cultura atual. (CARVALHO; ALVES, 2003, p. 6).

A segunda vertente da obra de Carvalho, ainda segundo Roxane, é a polêmica. Mas, se trata de uma variante da primeira. Como Olavo se coloca contra a "tirania da autoridade coletiva", e como sua obra é "de difícil compreensão", ele se utiliza de recursos irônicos e humorísticos para se comunicar com a população e com outros leitores que são leigos.

A obra de Olavo de Carvalho tem ainda uma vertente polêmica, onde, com eloquência contundente e temível senso de humor, ele põe a nu os falsos prestígios acadêmicos e as falácias do discurso intelectual vigente. Seu livro O Imbecil Coletivo: Atualidades Inculturais Brasileiras (1996) granjeou para ele bom número de desafetos nos meios letrados, mas também uma multidão de leitores devotos, que esgotaram em três semanas a primeira edição da obra, e em quatro dias a segunda. (CARVALHO; ALVES, 2003, p. 7).

Foi essa segunda vertente da obra de Carvalho, a polêmica, que o fez conhecido. Seu livro mais vendido “O mínimo que você precisa saber para não ser um idiota”, já citado, reflete essa popularização das suas ideias por conta da forma do seu discurso. E, apesar de o livro não ser um conteúdo que expressa sua obra em relação à filosofia ou às religiões comparadas (assuntos os quais Carvalho afirma que é sua prioridade), é ele que serve de base para a formulação de ideias e propostas dos movimentos conservadores brasileiros.

O livro foi organizado pelo jornalista Felipe Moura Brasil, consistindo em uma coletânea de 193 artigos e ensaios escritos entre 1997 e 2013, que foram publicados em diversos veículos da imprensa brasileira. A divisão dos artigos acontece em capítulos gerais ou macrotemas, que por sua vez se desdobram em subtemas. Os assuntos abordados são vários: juventude, conhecimento, socialismo, democracia, educação, religião, militância etc. Mas, apesar da variedade de assuntos, o foco é somente um: descrever e criticar as ideias e movimentos socialistas. Pode-se assegurar que essa obra de Carvalho é um compêndio de 
ideias antissocialistas. Não é à toa que o livro é intitulado "O mínimo que você precisa saber para não ser um idiota": ser idiota, para o organizador, é ser socialista - e o mínimo que você precisa saber para não ser um idiota é a "verdade" sobre o que é socialismo. Na sua apresentação do livro, o organizador Felipe Moura Brasil descreve que as ideias de Olavo de Carvalho são superiores e que ele escreve o livro para compartilhar o conteúdo na "esperança de que [o leitor ao ter contato com a obra de Olavo de Carvalho] se afaste da condição de bichinho e se eleve à altura dos anjos". (p. 23).

Apesar disso, quando Carvalho ou Brasil falam de "socialistas" ou "socialismo", o significado não está restrito à definição marxista do termo. No socialismo, a ideia defendida é uma associação voluntária de indivíduos, com finalidades comuns, dotados de uma partilha dos bens e dos meios de produção, contradizendo o ideal capitalista. Socialismo e comunismo distinguem-se somente quanto ao grau, sendo o segundo uma evolução (ou o próximo estágio) do primeiro. (CHAMPLIN; BENTES, 1991). Contudo, para fins semânticos e políticos, acabam significando a mesma coisa. Ou seja, dentro deste grande grupo, há: comunistas, marxistas, progressistas, antirracistas, feministas, ambientalistas, ativistas LGBT e vários outros.

Para ambos, Olavo de Carvalho e Felipe Moura Brasil, o socialismo é a principal doença da nação e da política brasileira. Essa "ideologia" se reflete e se propaga na cultura, na universidade, nas ações dos governos de centro e de esquerda, na imprensa, na juventude, na educação, entre outros, na forma do marxismo cultural. Não só isso, o socialismo também está no mundo todo, sendo, segundo Olavo de Carvalho, uma das três forças polares com planos de dominação mundial. (CARVALHO; DUGIN, 2012). O ex-presidente americano Barack Obama, seguindo a lógica, também pode ser enquadrado como socialista. O conservadorismo antissocialista, portanto, torna-se o remédio contra essas ideias, que se revelam como contrárias a um tradicionalismo, à fé cristã, à liberdade em todos os aspectos e ao fim da cultura e civilização ocidental.

Independente ou não das ideias contidas nesse livro não expressarem a obra filosófica de Carvalho, foram essas que mais se popularizaram; além disso, foram as que tiveram influência na fundação de vários movimentos conservadores. O próprio Olavo de Carvalho se define como parteiro da direita brasileira contemporânea e por muitos é considerado o "guru" (líder ideológico) do governo Bolsonaro.

Isso nos leva as seguintes perguntas: como Olavo de Carvalho conquistou Jair Bolsonaro ou viceversa? Quem possui mais influência nos movimentos direitistas? Bolsonaro é olavista ou Olavo que é bolsonarista? Quando ocorreu este encontro da teoria política com a ação política? Consideramos importante tecer algumas explicações para elucidarmos a relação do atual Presidente da República com Olavo de Carvalho. Todavia, antes falaremos sobre a biografia de Jair Bolsonaro.

Jair Messias Bolsonaro nasceu em Glicério (SP), no dia 21 de março de 1955, mas foi registrado em Campinas (SP). É descendente de imigrantes italianos, que chegaram ao Brasil depois da Segunda Guerra Mundial. Filho de Percy Geraldo Bolsonaro e de Olinda Bonturi Bolsonaro, atualmente se encontra casado com Michelle de Paula Firmo Reinaldo. É pai de cinco filhos. Os primeiros três, Flávio, Carlos e Eduardo, foram eleitos, respectivamente, como senador pelo estado do Rio de Janeiro (2018); vereador do município do Rio de Janeiro (2020) e deputado federal pelo estado de São Paulo (2018). 
Jair Bolsonaro concluiu o curso de formação de oficiais da Academia Militar das Agulhas Negras (Aman), em Resende (RJ), e o curso de paraquedismo militar na Brigada Paraquedista do Rio de Janeiro no ano de 1977. Em 1983, formou-se em educação física na Escola de Educação Física do Exército e tornouse mestre em saltos pela Brigada Paraquedista do Rio de Janeiro. Seguindo carreira militar, tinha a patente de capitão e exercia sua função no $8^{\circ}$ Grupo de Artilharia.

Até o dia 3 de setembro de 1986, Jair Bolsonaro era uma figura anônima perante a população. Foi um artigo que publicou na revista Veja que o fez conhecido. No texto, culpava os baixos salários, e não a indisciplina (como Exército fez crer), pelos desligamentos dos cadetes da Aman. O artigo the rendeu uma punição e acabou sendo preso por "transgressão grave". Um ano depois, no dia 25 de outubro de 1987, a mesma revista Veja divulgou uma reportagem afirmando que "o capitão Bolsonaro e outro militar, Fábio Passos, elaboraram um plano que previa a explosão de bombas em unidades militares do Rio para pressionar superiores". Um processo foi instaurado, Bolsonaro negou o plano e, ao fim de todos os trâmites, os ministros do STM consideraram Bolsonaro "não culpado" das acusações.

Em 1988, Bolsonaro foi eleito vereador no Rio de Janeiro pelo PDC (Partido Democrata Cristão). No mesmo ano de sua primeira eleição, acabou sendo "excluído do serviço ativo do Exército", passando a integrar a "Reserva Remunerada". Essa expulsão o impediu de atuar de forma direcionada à classe que o elegeu: os militares, principalmente os de baixa patente. Esse seu primeiro mandato como vereador durou apenas dois anos, pois sua popularidade entre o meio o fez se eleger deputado federal também pelo PDC em 1990. (FOLHA DE S.PAULO, 2018). Bolsonaro seria reeleito para mais sete mandatos consecutivos, todos para representar o estado do Rio de Janeiro. Suas principais bandeiras incluíam, segundo o jornal Folha de S.Paulo: a luta pela melhoria salarial dos militares; o fim da estabilidade dos servidores; defesa do controle de natalidade; e a revisão da área dos índios ianomâmis.

Ao longo de sua carreira como deputado, Bolsonaro aprovou somente dois projetos de lei. Viraram lei uma proposta que estendia o benefício de isenção do Imposto sobre Produto Industrializado (IPI) para bens de informática e outro que autorizava o uso da chamada "pílula do câncer": fosfoetanolamina sintética. $\mathrm{O}$ fato de ter aprovado os dois projetos de lei não significa que sua atuação tenha sido limitada. $\mathrm{O}$ que queremos ressaltar com esse fato é que Bolsonaro não ficou popular - e conhecido entre movimentos conservadores - por conta de sua atuação parlamentar, mas sim por conta das polêmicas nas quais se envolveu enquanto exercia a função ${ }^{17}$.

Por volta do ano de 2012, Olavo de Carvalho reaparecia no cenário nacional com duas ações: a primeira, um programa de rádio, o True Outspeak, gravado na forma de podcast e postado em uma rede social (Blog Talk Radio); e a segunda, um curso de filosofia de sua autoria, ministrado no site de um dos seus institutos, o Seminário de Filosofia. O programa servia como um mecanismo de extensão e divulgação do seu curso de filosofia. O sucesso do seu programa em grupos conservadores atraiu vários novos alunos. Entre esses estavam Flávio Bolsonaro, Carlos Bolsonaro e Eduardo Bolsonaro: os três primeiros filhos de Jair Bolsonaro, que na altura já eram parlamentares. Pode-se dizer que os caminhos de Bolsonaro e Olavo de Carvalho se encontraram nesse momento, durante a ascensão de ambos, quando aos poucos se inseriam na cultura popular. Bolsonaro estava cheio de polêmicas, mas vazio de conteúdo e de um ideário. Ao mesmo 
tempo, Olavo possuía um ideário conservador característico muito forte, mas não tinha oportunidade de ação política. Não é difícil presumir que Olavo percebeu que Bolsonaro tinha potencial. Afinal, o Brasil estava passando por uma onda conservadora, em que discursos favoráveis ao tradicionalismo nos costumes e ao liberalismo de mercado tornavam-se populares na classe média. Se Bolsonaro fizesse um bom trabalho de comunicação, viria a ser um fenômeno eleitoral. Ainda nos primeiros anos da década de 2010, Olavo declarava voto em Jair Bolsonaro e afirmava em postagens públicas em suas redes sociais que "a única solução para o Brasil era elegê-lo para presidente". Na época, a maior demonstração de que ambos estavam unidos foi a condecoração que Flávio Bolsonaro concedeu a Olavo de Carvalho no ano de 2012. A medalha Tiradentes, a mais importante do estado do Rio de Janeiro, foi entregue ao vivo em seu programa True Outspeak.

O grupo de alunos de Olavo de Carvalho trabalhou em demasia para montar uma imagem conservadora de Bolsonaro e popularizá-lo entre as massas. Esse grupo de intelectuais compartilhava dos mesmos valores da direita política, publicando diversos materiais nas redes sociais e em sites da internet. Entre os alunos de Olavo de Carvalho que publicavam, estava o jornalista Felipe Moura Brasil, que editou e organizou o livro "O mínimo que você precisa saber para não ser um idiota". As manifestações de julho de 2013 foram a primeira oportunidade dos seguidores de Jair Bolsonaro e Olavo de Carvalho se apresentarem ao público. Contudo, foi apenas em 2015 e 2016, com as manifestações antipetistas e favoráveis ao impeachment da presidente(a) Dilma Rousseff, que eles atuaram de forma organizada e coadunada. Os militantes começaram a se movimentar com cartazes pelas ruas com os dizeres "Olavo tem razão" e "Bolsonaro presidente".

Após a eleição de Jair Bolsonaro para a presidência em 2018, Olavo passou a exercer certa influência dentro do governo, indicando alguns ministros. Em certo momento, chegou a ser convidado para ser ele mesmo o ministro da educação ou da cultura. Porém, recusou o convite por afirmar que "conhecia seus limites" e que "não tinha uma grande capacidade administrativa" (apesar de dizer que "sabe o que precisa ser feito", não conseguiria "ficar pensando nisso todo dia"). Entretanto, disse que aceitaria ser embaixador do Brasil nos Estados Unidos da América. O convite nunca foi feito por Bolsonaro, que acabou indicando o diplomata Nestor Foster para a embaixada. (BRANT, 2018). O que é importante ressaltar dessa relação é o movimento político-social-filosófico que ambos criaram e que mantém, ainda nos dias de hoje, diversos defensores. Ambos se "completam", pois Olavo não teria poder político sem Bolsonaro - e Bolsonaro não teria "conteúdo teórico" ou propostas sem Olavo. E apesar de Olavo de Carvalho, em alguns momentos, ter disparado certas "broncas" a Bolsonaro (o que causa certo impacto político), nenhum dos dois sinalizou rompimento ${ }^{18}$.

\section{As propostas bolsolavistas para a educação}

Seguindo o que foi apresentado no capítulo anterior, detalharemos (no que consistem, histórico e críticas) as propostas bolsolavistas para a educação com base na produção científica selecionada. 


\section{Escola sem Partido}

Antes de falar sobre o movimento Escola sem Partido, é importante explicar o que é doutrinação. Essa ideia e seu significado conceitual não estão necessariamente relacionados com o significado de seu vocábulo. Grupos conservadores acreditam que a escola é um lugar que está repleto de doutrinadores profissionais que impõe e ensinam os seus pontos de vista, suas ideologias e seus pensamentos próprios aos alunos (em vez de matérias e disciplinas).

Doutrinação é o ato ou o efeito de doutrinar. É fazer propaganda ou proselitismo. A palavra doutrina vem do latim doctrina, cuja forma verbal é docere, "ensinar". Portanto, tem o significado ou sentido de "ensino". Envolve ideias de crença, dogma, conceito ou princípio fundamental ou normativo em que certos atos se baseiam. Esse vocábulo traz imediatamente às nossas mentes ideias e ensinamentos religiosos, porque usualmente é assim que ouvimos ser dito. A expressão "a doutrina” pode aludir aos ensinamentos ou ao sistema de ensinos de alguma religião. Há um livro muito citado por movimentos conservadores que trata sobre doutrinação. É o "Maquiavel Pedagogo", de autoria do professor universitário francês de ciências da computação Pascal Bernardin, cuja $1^{a}$ edição foi publicada no ano de 1995. O autor argumenta que o problema da educação é sua “submissão a interesses políticos de esquerda". Logo na introdução do livro, Bernardin deixa claro o seu pensamento sobre como a educação é feita na contemporaneidade:

Uma revolução pedagógica baseada nos resultados da pesquisa psicopedagógica está em curso no mundo inteiro. Ela é conduzida por especialistas em Ciências da Educação que, formados todos nós mesmos meios revolucionários, logo dominaram os departamentos de educação de diversas instituições internacionais [...] Essa revolução pedagógica visa a impor uma "ética voltada para a criação de uma nova sociedade" e a estabelecer uma sociedade intercultural. A nova ética não é outra coisa senão uma sofisticada reapresentação da utopia comunista. $\mathrm{O}$ estudo dos documentos em que tal ética está definida não deixa margem a qualquer dúvida: sob o manto da ética, e sustentada por uma retórica e por uma dialética frequentemente notáveis, encontra-se a ideologia comunista [...] A partir de uma mudança de valores, de uma modificação das atitudes e dos comportamentos, bem como de uma manipulação da cultura, pretende-se levar a cabo a revolução psicológica e, ulteriormente, a revolução social. Essa nova ética [...] é obrigatoriamente ensinada em todos os níveis do sistema educacional. (2012, p. 6)

Para que os educadores-doutrinadores conquistem seus objetivos, segundo o autor, eles se utilizam de diversos mecanismos de doutrinação em sala de aula: testes psicológicos; informatização mundial das questões do ensino; asfixia ou subordinação do ensino livre; pretensão de anular a influência da família; investimento na formação de novos professores que defendam ideias progressistas; dar importância pública para a pedagogia e à psicopedagogia; redefinição do papel da escola (a prioridade já não é a formação intelectual, mas sim a "aprendizagem da vida social"); modificação dos valores que os alunos recebem de suas famílias, além do comportamento e atitudes desses; entre outros. Vale citar também que Bernardin escreve que, nas escolas, são "utilizadas técnicas de manipulação psicológica e de lavagem cerebral" e que toda a estrutura burocrático-administrativa da escola (e das instituições que a regulamentam e a controlam) é desenhada para beneficiar e/ou propiciar uma revolução cultural (até a organização das etapas, séries e ciclos curriculares e as avaliações). O site do Movimento Escola sem Partido conceitua doutrinação seguindo esses mesmos princípios: 
“As nossas escolas estão vazias de professores e repletas de doutrinadores, há um exército militando nas salas de aula, num afã constante para "mudar a realidade" e para formar "alunos conscientes" e tantos outros chavões que ouvimos da boca dos pedagogos". (2019).

Apesar de o movimento Escola sem Partido tomar para si esse conceito de doutrinação e até surgir com a motivação de combatê-la, as ideias trabalhadas no livro de Bernardin parecem não ter sido levadas em consideração para fundá-lo. A razão é que o livro se tornou popular no Brasil, sendo traduzido para o português, somente após a indicação do mesmo por Olavo de Carvalho em meados de 2010.

O idealizador da proposta é um advogado paulista, Miguel Nagib. Ele narra em vários momentos que a ideia do Escola sem Partido nasceu quando sua filha desenvolveu uma atividade em sua escola na qual o professor comparava São Francisco de Assis com o revolucionário argentino Ernesto "Chê" Guevara. Nagib, que é católico, não gostou da comparação e viu nela um elemento ideológico. Para ele, claramente o professor de sua filha estava tentando doutriná-la: ao comparar Guevara com um santo católico, o professor transmitia a ideia de que o socialismo era uma visão política perfeita e altruísta. Atualmente, a ideia de doutrinação vinculada a educação escolar está amplamente difundida, de modo que vários creem que a escola tem se tornado um lugar que possui esse propósito. Tatiana de Britto (2019, p.3) explica que tal movimento:

Caracteriza-se como uma "associação informal, independente, sem fins lucrativos e sem qualquer espécie de vinculação política, ideológica ou partidária” (Escola sem Partido, 2017). O movimento declara ter-se inspirado em iniciativa similar fundada nos Estados Unidos e alega que numerosas escolas no Brasil, públicas e privadas, da educação básica à educação superior, são alvo de elevado "grau de contaminação político-ideológica" em virtude da doutrinação por parte dos professores (Escola sem Partido, 2017). Segundo o movimento, haveria um proselitismo docente propagando ideologias esquerdistas, contrárias a diversos valores sociais, como a família tradicional e o livre-mercado, os valores cristãos e a própria ordem capitalista. Também haveria apropriação de direitos parentais relacionados ao ensino de preceitos morais conformes às convicções de cada família.

O projeto de legislação Escola Sem Partido (ESP) foi fundado por Nagib em 2004, mas foi apenas em 2015 que o movimento adquiriu forças para tentar implementar seu primeiro projeto de lei nas casas legislativas estaduais e municipais de todo o Brasil. Em 2016, foi submetido ao Senado por Magno Malta (PR-ES), na forma do Projeto de Lei nº 193 (PL-193, 2016), para ser incluído na Lei de Diretrizes e Bases da Educação Nacional (LDB). Segundo os fundadores do Escola Sem Partido, seria necessária uma mudança dentro das escolas, o que eles chamam de "liberdade de ensinar", partindo do princípio de que a laicidade e os direitos dos estudantes estão sendo ameaçados, assim como as tradições familiares. Como exemplo, é possível citar uma das justificativas da ementa mais recente do ESP, chamada de "ESP versão 2.0":

5) A liberdade de ensinar, obviamente, não confere ao professor o direito de se aproveitar do seu cargo e da audiência cativa dos alunos, para promover os seus próprios interesses, opiniões, concepções ou preferências ideológicas, religiosas, morais, políticas e partidárias; nem o direito de favorecer, prejudicar ou constranger os alunos em razão de suas convicções políticas, ideológicas, morais ou religiosas; nem o direito de fazer propaganda político-partidária em sala de aula e incitar seus alunos a participar de manifestações, atos públicos e passeatas; nem o direito de manipular o conteúdo da sua disciplina, com o objetivo de obter a adesão dos alunos a determinada corrente política 
ou ideológica; nem, finalmente, o direito de dizer aos filhos dos outros o que é certo e o que é errado em matéria de religião e de moral. (Escola sem Partido, 2019)

Até os dias de hoje, o movimento Escola sem Partido não foi implementando legalmente. Nesse sentido, o mais próximo que temos é o Projeto de Lei n’. 867 (PL-867, 2015) “Escola Livre”, inspirado no Escola Sem Partido e submetido à Câmara pelo deputado federal Izalci Lucas Ferreira (PSDB-DF). No estado de Alagoas, a lei foi sancionada pelo governador Renan Filho (MDB-AL). A Lei impunha punições aos professores que praticassem "doutrinações ideológicas" e determinava que os educadores mantivessem posicionamento "neutro" diante das disciplinas aplicadas. Todavia, em março de 2017, o programa foi suspenso pelo ministro do Supremo Tribunal Federal Luís Roberto Barroso. E no dia 22 de agosto de 2020 ocorreu um julgamento virtual no STF, no qual a lei foi derrubada.

Partindo do princípio de que vários autores serão contrários ao ESP, o movimento na verdade deseja criar um alarmismo falso de medo e criminalização das práticas educacionais, utilizando-se do atual cenário político para comprometer a educação pública e educadores cujo posicionamento é mais progressista, extirpando a pluralidade de pensamento. Outra proposta que também dialoga com o Movimento Escola Sem Partido é o Projeto de Lei nº 1411 (PL 1411/2015), apresentado pelo deputado federal Rogério Marinho (PSDB-RN) na Câmara dos Deputados, chamado de "Assédio Ideológico". Segundo o projeto,

Entende-se como Assédio Ideológico toda prática que condicione o aluno a adotar determinado posicionamento político, partidário, ideológico ou qualquer tipo de constrangimento causado por outrem ao aluno por adotar posicionamento diverso do seu independente de quem seja o agente. (OLIVEIRA; BATALHA, 2017, p. 48).

Todos os projetos contam com o apoio de diversos deputados, para os quais as escolas no Brasil, principalmente as públicas, vêm sofrendo processo de ideologização "esquerdista”, principalmente de professores que (segundo defensores do Escola sem Partido) passam a ser "adeptos do Partido dos Trabalhadores (PT)":

Tal programa afirma que o governo esquerdista do Partido dos Trabalhadores (PT), por ser marxista cultural, defende que a educação é muito influenciada pelo marxismo do educador Paulo Freire, que quer destruir os valores simples e humildes da população brasileira, incitando à revolução. (SEPULVEDA; SEPULVEDA, 2016, p. 149).

Nas eleições de 2018, o Escola sem partido tornou-se bandeira do então candidato Jair Bolsonaro. Não só isso, Bolsonaro realizou

uma campanha alinhada às pautas do EsP. Em um post do dia 10 de agosto de 2018, a página do Facebook do EsP apontava que Jair Bolsonaro era "o único candidato a Presidente da República a se comprometer publicamente com a aprovação do Escola sem partido e o combate à ideologia de gênero". Durante toda a sua campanha à presidência, Bolsonaro defendeu as bandeiras contra a doutrinação ideológica e a ideologia de gênero - principais pautas do EsP (LIMA; HYPOLITO, 2020, p. 11).

Ao propor uma escola sem "nenhum partido", o projeto, na verdade, estimula a intolerância, preconceito racial e até o ódio contra as minorias. O que está revestido de garantias dos direitos estudantis, na verdade, é o desejo de implantar um estilo de educação programada em que a censura e a liberdade vigiada estejam presentes, por exemplo, em cartazes nas salas de aulas com “deveres" dos professores, aulas gravadas pelos educandos e denúncias. O ESP deixa tudo esclarecido em seu site, onde existe uma aba em 
que é possível ler denúncias feitas contra professores da educação básica e superior (que descumpriram as supostas “regras”). Além disso, o conjunto de ideias expressas pelo movimento Escola sem Partido

em grande medida encontram relação com os discursos de alguns setores militares, expressos principalmente em publicações da editora Biblioteca do Exército (Bibliex), quando fazem um balanço acerca da ditadura e da transição democrática. Embora se considerem vencedores da "guerra" contra as organizações da esquerda, depois da "transição democrática" os militares entendem que continuaram a enfrentar, agora ideologicamente, essa mesma esquerda. Esses subversivos atuariam na imprensa, nos governos e no parlamento, buscando vingança e recusando-se a aceitar a "anistia para os dois lados". Para os militares haveria ainda lutas a serem travadas, dessa vez não no campo de batalhas, mas nas disputas de memória que empreendem contra aqueles que estariam, contemporaneamente, constantemente desqualificando suas ações do passado (SILVA, 2018, p. 170).

Deve-se partir do princípio de que a escola precisa ser um ambiente onde as diferenças sejam aceitas, que dessa liberdade seja possível desenvolver um trabalho escolar autônomo. Privar a escola da pluralidade, das discussões sobre gênero e sexualidade, dos debates de "temas polêmicos", resume-se a deduzir que a educação trata da mera transferência de conhecimento. Ademais, o fato é que cada educador progressista e que promove a dignidade humana carrega dentro de si a responsabilidade de que seus alunos possam ser pessoas críticas e curiosas diante da sociedade. Paulo Freire, referência como educador e alvo de calúnia constante da Escola Sem Partido, deixa claro no livro Pedagogia da Autonomia (1996, p. 13) que saber ensinar não é transferir conhecimento, mas criar as possibilidades para a sua própria produção ou a sua construção. Em suma, o projeto Escola sem Partido é uma iniciativa que mantém os "poderes hegemônicos" na sociedade contemporânea, possuindo propósitos políticos, de matriz conservadora (ou seja, o Escola sem Partido não é neutro como se propõe inicialmente).

\section{O combate à "ideologia de gênero"}

Ivanderson da Silva (2019) realizou uma pesquisa buscando entender o que significa a expressão "Ideologia de Gênero". No resumo de seu artigo, "Em Busca de Significados para a expressão "Ideologia de Gênero", podemos ver algumas de suas conclusões:

Essa pesquisa investigou os significados que têm sido produzidos pela expressão "Ideologia de Gênero" no cenário contemporâneo. De modo específico o estudo objetivou fazer um mapeamento de publicações que contenham essa expressão em seu título e/ou resumo, explorar suas definições, bem como as propostas que são apresentadas. Trata-se de uma investigação de natureza qualitativa, do tipo bibliográfica, que se amparou na abordagem da revisão sistemática de literatura. Inicialmente foi realizada uma busca no "Google Acadêmico" pela expressão "Ideologia de Gênero". Foram acessadas as 20 primeiras páginas. Foram identificados 26 arquivos. Esse material foi lido e analisado e como resultado se constatou que a expressão "Ideologia de Gênero" tem assumido pelo menos três significados gerais: o machismo e a LGBTIfobia como ideologias de gênero; "Ideologia de Gênero" como um prelúdio do apocalipse moral (no campo religioso e no campo legislativo); e "Ideologia de Gênero" como uma falácia. (2019, p. 1).

Como podemos ver, o significado de tal expressão não é objetivo. Porém, há uma intenção por parte dos conservadores em argumentar a favor dela. Na maioria das vezes, ideologia de gênero não está relacionada a estudos de gênero. Segundo Junqueira, 
a "Ideologia de Gênero" "não corresponde e nem tampouco resulta do campo dos Estudos de Gênero ou dos movimentos feministas e LGBTI". Trata-se de um conceito "elaborado por intelectuais católicas/os convocadas pelo Vaticano para articular a resistência contra o avanço das pautas feministas" (CARVALHO; SÍVORI, 2017, p. 3). Segundo Biroli (2015, s/p.) "trata-se da ação retrógrada, [...] para frear e interromper a consolidação de valores básicos da democracia, como o tratamento igual aos indivíduos [...] e a promoção, [...] do respeito à pluralidade e diversidade”. (2017, p. 45-46).

O conceito de "ideologia de gênero" é polissêmico. (MAIA; ROCHA, 2017). O termo “ideologia" é utilizado como arma política com claros desenhos de desqualificação de estudos de gênero e diversidade sexual baseada numa matriz heterossexual. (BUTLER, 2013). A história do termo "ideologia de gênero", inclusive, perpassou as tramitações do PNE de 2012 até sua aprovação em 2014. Ele ganhou forças durante as discussões e foi apresentado pelo discurso político-religioso conservador como a tentativa de "sexualizar precocemente" crianças e fazer do "homossexualismo" uma prática "normal" (MARANHÃO et al., 2018).

O que precisa ficar claro é que, ao realizar discussões, projetos e rodas de conversas sobre o tema gênero e sexualidade dentro da escola, os educadores não estão incentivando os educandos a serem de outro gênero, mas sim tentando torná-los seres críticos, questionadores quanto à violência e discriminação a pessoas LGBTQIA+. Para explicarmos a "ideologia de gênero" a partir de uma perspectiva científica e crítica e definir o que de fato é o gênero, pode-se usar a definição da Organização Pan-Americana de Saúde (2019). No subtítulo "principais informações” encontramos que:

O gênero se refere às características socialmente construídas de mulheres e homens como normas, papéis e relações existentes entre eles. As expectativas de gênero variam de uma cultura para outra e podem mudar ao longo do tempo. Também é importante reconhecer identidades que não se encaixam nas categorias binárias de sexo masculino ou feminino.

Como forma de assegurar os direitos dessa parcela da população, documentos como os "Princípios de Yogyakarta: Princípios sobre a aplicação da legislação internacional de direitos humanos em relação à orientação sexual e identidade de gênero", foram criados. Para desenvolver esse documento específico, uma reunião foi realizada na Indonésia, em 2007, com vinte e cinco países (contando com o Brasil). Foi definido, na forma de um guia, os princípios e normas para o cumprimento da Legislação Internacional de Direitos Humanos em relação à Orientação Sexual e Identidade de Gênero. No princípio dezesseis, "Direitos à Educação", nos pontos “c" e "d", temos as seguintes normas:

c) Garantir que a educação seja direcionada ao desenvolvimento da personalidade de cada estudante, de seus talentos e de suas capacidades mentais e físicas até seu potencial pleno, atendendo-se as necessidades dos estudantes de todas as orientações sexuais e identidades de gênero". (2007, p. 24).

d) Assegurar que a educação seja direcionada ao desenvolvimento do respeito aos direitos humanos e do respeito aos pais e membros da família de cada criança, identidade cultural, língua e valores, num espírito de entendimento, paz, tolerância e igualdade, levando em consideração e respeitando as diversas orientações sexuais e identidades de gênero." (2007, p. 24).

O Escola sem Partido dialoga diretamente com o desenvolvimento do termo "ideologia de gênero”. Afinal, ambos desejam implementar na educação a inibição de propostas políticas que discutam sobre questões de gênero, sexo e sexualidade e que se refletem diretamente na persistência das desigualdades sociais. Sob uma das principais justificativas para forçar a "Ideologia de gênero", o ESP juntamente com 
aqueles que os apoiam, dizem veemente que a moral da "família tradicional cristã" está sendo vilipendiada. Posicionar-se contra a "ideologia de gênero", portanto, é posicionar-se favoravelmente a esses valores tradicionais. É desejar um ensino neutro, sem qualquer tipo de influência ideológica (que, nesse caso, é de esquerda).

\section{Homeschooling}

De acordo com os principais historiadores da educação no Brasil, o ensino domiciliar ou ensino em casa existe desde a chegada dos primeiros portugueses ao Brasil, e hoje tem sido identificado por pesquisadores como um fenômeno nacional e internacional. O homeschooling - educação domiciliar, ou ensino em casa - significa a prática em que os pais ou responsáveis assumem a responsabilidade pela escolarização do filho em desobrigação às instituições próprias e formais de ensino, buscando a prevalência das liberdades individuais e o não intervencionismo estatal.

Uma medida provisória que autorize os pais a não matricularem seus filhos em escolas regulares, passando a educá-los em casa, vem sendo anunciada pelo governo Bolsonaro desde o início do seu mandato. Tal proposta foi convertida em Projeto de Lei, em abril de 2019, elaborado pela atual Ministra da Mulher, da Família e dos Direitos Humanos, Damares Alves. Ademais, o tema é um dos pilares da gestão de Bolsonaro, estando na lista das metas prioritárias do Governo. O Projeto de Lei 2401/19 estabelece que os pais que optarem pelo ensino domiciliar terão que formalizar a escolha junto ao Ministério da Educação e renová-la anualmente, por meio de plataforma virtual do MEC, com a inclusão do plano pedagógico individual correspondente ao novo ano letivo. Além disso, o estudante matriculado em educação domiciliar será submetido, para fins de certificação da aprendizagem, a uma avaliação anual sob a gestão do Ministério da Educação (BRASIL, 2019).

O projeto encontra-se em tramitação e entre os principais argumentos para a sua defesa estão a possibilidade de ofertar às crianças contextos mais seguros, de modo que elas não estejam em espaços (escolas) suscetíveis de violência, combate a bullying, questões econômicas e de mercado, mas principalmente e fundamentalmente o direito dos pais de educarem de acordo com seu valores, suas regras e suas crenças. Esse último argumento, que é o mais explorado pelos agentes que defendem o projeto, conecta-se com os demais eixos da agenda moralizadora que apresentamos, através da ideia de que o Estado não deve ser responsável por determinar temáticas e conteúdos a serem abordados nas escolas. Tais projetos e a concepção de que a família tem competência para definir os conteúdos abordados pela escola vêm sendo duramente criticados por setores do campo educacional e dos movimentos sociais, especialmente os que possuem relação com a atuação docente. Segundo Cunha (2016), tais projetos negam à criança como um sujeito de direitos, com tentativa de substituição do poder do Estado pelo poder da família. Soma-se a essa percepção a de que eles inviabilizam o caráter republicano da escola.

No atual cenário não há legislação que vede ou permita de forma direta a educação domiciliar, no entanto, há muito tempo entende-se que o ensino regular das crianças e dos adolescentes cabe ao sistema de ensino vigente, ou seja, às redes de escolas públicas e privadas. Sendo assim, a educação escolar é um 
direito fundamental das crianças e adolescentes, cabendo aos pais ou responsáveis o dever de matricular seus filhos a partir dos 4 anos nas escolas e cuidar da frequência deles, assim como ao Estado a responsabilidade paralela de efetivação deste direito, em conjunto com os pais. De acordo com a ANED (Associação Nacional de Educação Domiciliar), dentre os motivos pelos quais os pais escolhem tal modalidade, está o desejo de maior controle sobre a educação do filho.

Tanto os céticos quanto os defensores da educação domiciliar concordam que uma das causas principais que levam à opção por tal modalidade é, sem dúvida, a descrença na escola, em sua qualidade, segurança e na confiabilidade de seu papel enquanto espaço de socialização e transmissão de valores, informações e conteúdos para a formação efetiva do cidadão. (ARRUDA; PAIVA, 2017, p. 33).

Da mesma forma, Góes e Souza (2019) entendem que a demanda pela educação domiciliar é reflexo da falha de prestação do serviço público de ensino. De acordo com o Ministro Luiz Fux, em seu voto no julgamento que negou provimento ao Recurso Extraordinário (RE) 888815, no qual se discutia a possibilidade de o homeschooling ser considerado como meio lícito de cumprimento, há inconstitucionalidade na matéria por essa ser incompatível com os dispositivos constitucionais, dentre eles a obrigatoriedade de os pais matricularem seus filhos em instituições de ensino. Destacou-se em seu voto, também, a importância da função socializadora da educação. Apoiando o entendimento de Fux, Lewandowski afirma que "o risco seria a fragmentação social e desenvolvimento de 'bolhas' de conhecimento, contribuindo para a divisão do país, intolerância e incompreensão". (STF, 2018). Da mesma forma, Marco Aurélio acredita que "textos legais não permitem interpretações extravagantes. Há uma máxima em hermenêutica segundo a qual onde o texto é claro não cabe interpretação", afirmando, categoricamente, que a legislação brasileira não dá respaldo para que seja praticada a educação domiciliar. (STF, 2018).

Muito se discute sobre o direito de liberdade dos pais em escolher a forma de educar seus filhos, no entanto, a legislação, por diversas vezes, deixa claro que o Estado deve fornecer a educação, devendo a família participar de forma complementar. O que fica claro, contudo, é que a proposta do homeschooling tem a mesma natureza e é defendida entre os mesmos grupos que defendem o movimento Escola sem Partido e outras propostas de matriz conservadora (ideologia de gênero, escola cívico-militares, entre outras, já ressaltadas neste trabalho). Para Nacif e Filho,

Num campo com tantos desafios como é a Educação, o homeschooling foi colocado como uma temática prioritária do governo Jair Bolsonaro para os primeiros 100 dias de governo. A defesa do homeschooling no Brasil tem como principal motor grupos ultraconservadores cristãos que se organizam nessa direção. São os mesmos grupos da sociedade e parlamentares que também defendem o projeto Escola sem Partido, e que combatem uma suposta doutrinação comandada por professores. (2019, p. 241-242).

A defesa do homeschooling, bem como a defesa dos mais importantes programas do governo Bolsonaro têm em comum o aspecto ideológico. O objetivo é desconstruir a ideologia de esquerda (que segundo eles, está presente nas escolas) e intensificar a ideologia da direita. Propostas como o Projeto Escola Sem Partido e o homeschooling são claras expressões da tentativa de promover uma formação específica para os alunos ou, em última instância, retirá-los da escola (porque essa promove o "esquerdismo"). 


\section{Escolas cívico-militares}

O Programa Nacional das Escolas Cívico-Militares (Pecim) foi instituído pelo Decreto n .10 .004 , de 5 de setembro de 2019, e regulamentado pela Portaria $n^{\circ} .2015$, de 20 de novembro de 2019. A meta é inaugurar 216 escolas cívico-militares no Brasil até 2023. Segundo o decreto, "o programa tem a finalidade de promover a melhoria na qualidade da educação básica no ensino fundamental e no ensino médio". Para compreender a proposta, podemos apelar a um argumento de ordem técnica, menos significativo, e a outro de ordem biográfica, por assim dizer, que é mais determinante.

Escolas militares apresentam desempenho superior ao de escolas públicas comuns, inclusive no Exame Nacional do Ensino Médio (Enem). (BENEVIDES; SOARES, 2020). Entretanto, o resultado parece justificar-se menos pelo modelo da escola do que pelo investimento por aluno, que é cerca de três vezes maior nas instituições militares ( $\mathrm{R} \$ 19$ mil por aluno/ano contra $\mathrm{R} \$ 6$ mil). (CAFARDO; JANSEN, 2018). A discrepância orçamentária é significativa demais para ser inócua. Além disso, o desempenho de outras escolas federais e técnicas, apesar do orçamento ligeiramente menor, é superior ao de escolas militares no Enem. Em todo caso, não se podem comparar instituições que, afora o orçamento mais generoso, ainda submetem os potenciais alunos a processos seletivos com outras que são obrigadas a admitir qualquer um que pleiteia a vaga. Sem contar o nível socioeconômico dos alunos, que é tão mais alto quanto melhor o desempenho das escolas.

Como dissemos, o Plano Nacional de Escolas Cívico-Militares não pode ser compreendido sem se apelar à biografia do presidente da República. Jair Bolsonaro era capitão do exército, dedicou seus mandatos legislativos aos militares e nomeou-os para muitos cargos importantes no governo. O ethos (a ética), o pathos (a emoção) e o logos (lógica) do presidente são todos militaristas. O Pecim, portanto, é mais revelador sobre quem é Bolsonaro do que sobre o que são as escolas militares. E o programa não faria sentido se o presidente não fosse um ex-militar orgulhoso da corporação a que pertenceu. Atualmente, o programa encontra-se na fase piloto e, segundo o MEC, 54 escolas públicas estão aptas a se tornarem escolas cívico-militares. Espírito Santo, Sergipe, Piauí e Alagoas ficaram de fora por não atenderem todos os critérios necessários para ingressar no Pecim, ou por não estarem de acordo com as medidas educacionais que o projeto deseja implantar nas escolas.

O MEC estabelece os seguintes critérios para que uma escola pública se torne cívico-militar: (1) com alunos em situação de vulnerabilidade social; (2) com desempenho abaixo da média estadual no Índice de Desenvolvimento da Educação Básica (Ideb); (3) preferencialmente, com o número de matrículas de 501 a 1.000; (4) com a oferta das etapas anos finais do ensino fundamental regular e/ou ensino médio regular; (5) com a oferta de turno matutino e/ou vespertino, excetuando-se o noturno; e (6) com a aprovação da comunidade escolar para a implantação do modelo (BRASIL, 2020). Segundo o último critério, é necessário que a comunidade escolar deseje a implantação do modelo, porém, uma das falas do presidente Jair Bolsonaro deixa o questionamento sobre a decisão ser um direito da comunidade escolar:

\footnotetext{
"Me desculpa, não tem que aceitar não. Tem que impor. Se aquela garotada está na quinta série e na prova do Pisa não sabe uma regra de três simples, não sabe interpretar um texto, não responde a uma pergunta básica de ciência, me desculpa, não tem que
} 
perguntar para o pai, irresponsável nesta questão, se ele quer ou não uma escola, de certa forma, com militarização. Tem que impor, tem que mudar" (AMARAL, 2019).

Os militares ajudarão a decidir o plano pedagógico, gestão escolar e administrativa das escolas que participarem do Pecim. Segundo o decreto nº 10.004, de 5 de setembro de 2019, cabe ao Ministério da Educação escolher o perfil dos militares e fazer o processo seletivo daqueles que estão inativos nas Forças Armadas e desejam trabalhar por um tempo determinado nas escolas. O primeiro decreto que estabelece a junção dos militares às escolas públicas é o decreto n. 9.940, de 24 de julho de 2019, que altera o item 10 do $\int 1^{\circ}$ do art. 21 do Decreto $n^{\circ} .88 .777$, de 30 de setembro de 1983 e aprova a educação básica com gestão em colaboração com os policiais militares e corpos de bombeiros militares.

É importante ressaltar também o art. $3^{\circ}$ do Pecim onde estão descritos os princípios do programa, como a promoção de educação básica de qualidade aos alunos das escolas públicas regulares estaduais, municipais e distritais (I), o atendimento preferencial às escolas públicas regulares em situação de vulnerabilidade social (II), o desenvolvimento de ambiente escolar adequado que promova a melhoria do processo ensino-aprendizagem (III), a gestão de excelência em processos educacionais, didáticopedagógicos e administrativos (V), o fortalecimento de valores humanos e cívicos (VI), a adoção de modelo de gestão escolar baseado nos colégios militares (VII), pelos princípios, podemos concluir e supor que o programa não seguirá a gestão democrática imposta pela constituição e pela Lei e Diretrizes de Base da Educação Nacional (LDB) e sim substitui-la pelo modelo de gestão e excelência dos colégios militares baseado na hierarquia e na rígida disciplina. Além disso, os princípios III e V discorrem também sobre as medidas que deverão ser tomadas para diminuir os índices de violência dentro das escolas públicas.

Apesar do grande investimento nesse programa por parte do Governo Federal, também é possível compreender que, em vez de tratar dos problemas de raízes profundas da educação pública que estão ligados à segurança dos alunos, de garantia de educação de qualidade, de melhoria nos salários dos professores e, principalmente, do investimento financeiro, o governo escolheu implantar essa "nova" abordagem educacional. A esse respeito, Martin (2019) complementa que o Estado policial, nesse momento, alcançaria o dia a dia das escolas instituindo condutas compatíveis com os valores da ordem. Embora compreendamos muitas das dificuldades dos profissionais da educação ao considerarmos a temática da violência, assim como a preocupação dos pais em relação a seus filhos, esse apelo pela militarização pode promover o efeito de silenciamento e consequente exclusão dos alunos, famílias e professores". Com essas considerações, podemos apontar que o Programa Nacional das Escolas Cívico-militares se configura como uma nova estratégia de implementação do ideário defendido pelo movimento Escola Sem Partido (DA NOVA; BONETTI, 2020).

\section{Considerações finais}

Acreditamos que o século XXI vem acompanhado de um aumento de propostas assumidamente ideológicas ${ }^{19}$ para os mais diversos aspectos, setores e lugares sociais. Os movimentos assumidamente ideológicos estão cada vez mais presentes e as conjunturas políticas estão cada vez mais polarizadas. 
Simultaneamente, ideias de direita têm aparecido nos cenários políticos, o que é seguido por crises institucionais de movimentos de centro e movimentos de esquerda (ambos das mais diversas matrizes). E os movimentos políticos de direita expressam cada vez mais suas ideias e propostas para a educação. No caso do Brasil especificamente, a direita conservadora propõe para a educação projetos como a militarização das escolas, o Escola sem Partido, o fim da (do que se quis chamar pejorativamente como) ideologia de gênero e o bomeschooling.

Das propostas discutidas neste trabalho (escola sem partido, ideologia de gênero, escolas cívicomilitares e homeschooling), todas são direcionadas a silenciar o pensamento plural na escola, controlar o que é dito na sala de aula ou mesmo mudar a estrutura de toda a educação (seja implantando uma escola controlada por militares, seja dando a possibilidade de pais educarem seus filhos de acordo com seu pensamento). Visam sobretudo a manter um estado de coisas, as distinções sociais e a desigualdade social que faz girar a roda do capital. Vivemos em um país extremamente violento, racista e misógino. Tais propostas antiprogressistas buscam manter a instabilidade dessas formas de controle e dominação. Não há, entre os bolsolavistas, profundidade científica em suas propostas. Foi possível verificar, por meio da produção analisada, que o objetivo é claramente político e serve a um projeto específico de sociedade.

Esse processo na educação brasileira, no qual está incluso o desmonte de diversas instituições, além do desmoronamento organizado de diversas conquistas, levará a um retrocesso de conquistas educacionais e perdurará enquanto grupos conservadores detiverem influência na formação de políticas públicas para a educação. Contudo, ainda não é possível prever quais serão os efeitos e consequências dessas medidas e propostas caso elas sejam adotadas em sua integralidade. O futuro da educação brasileira ainda será decidido por meio dessa disputa intelectual entre dois grupos. O conflito tem, de um lado, grupos conservadores bolsolavistas; e do outro, grupos de ideologias e movimentos sociais diversos, que entendem que a educação não pode ser vítima de políticas que objetivam cercear a liberdade de atuação dos professores, as discussões sobre gênero e identidade, a pluralidade de metodologias e técnicas de ensino (e suas discussões que são comuns, científicas e construtivas), entre outros valores democráticos, participativos, horizontais e liberais.

\section{Referências:}

AMARAL, Luciana. Bolsonaro lança programa para implementar escolas cívico-militares. UOL, 5 set. 2019. Disponível em: <https://educacao.uol.com.br/noticias/2019/09/05/bolsonaro-lancaprograma-para-implementar-escolas-civico-militares.htm>. Acesso em: 24 jan. 2021.

ANDRADE, Guilherme Ignácio F. A trajetória da extrema-direita no Brasil: integralismo, neonazismo e revisionismo histórico (1930-2012). In: Simpósio Internacional Lutas Sociais na América Latina "Revoluções nas Américas: passado, presente e futuro", 5., Anais..., p. 75, 2013.

ARRUDA, J. G. S.; PAIVA, F. S. Educação domiciliar no Brasil: panorama frente ao cenário contemporâneo. EccoS, São Paulo, n. 43, p. 19-38. maio/ago. 2017.

BARRETO, Raquel Goulart. Tecnologia e educação: trabalho e formação docente. Educação e Sociedade. Campinas, v. 25, nº. 89, p. 1181-1201, set./dez. 2004 
BARRETTO, Eduardo. Bolsonaro apresenta proposta ao PP para concorrer à Presidência da República, O Globo, [s. l.], 24 abr. 2014. Disponível em: <https://oglobo.globo.com/brasil/bolsonaroapresenta-proposta-ao-pp-para-concorrer-presidencia-da-republica-12298428>. Acesso em: 25 fev. 2021.

BENEVIDES, Alesandra de Araújo; SOARES, Ricardo Brito. Diferencial de desempenho de alunos das escolas militares: o caso das escolas públicas do Ceará. Nova econ., Belo Horizonte, v. 30, n. 1, p. 317-343, jan/2020.

BERNARDIN, Pascal. Maquiavel Pedagogo: ou o ministério da reforma psicológica. Tradução de Alexandre Muller Ribeiro. 1 ed. Ecclesia e Vide Editorial. Campinas, São Paulo: 2012.

BIROLI, Flávia. Divisão sexual do trabalho e democracia. In: ENCONTRO DA ANPOCS, 39., 2015, Caxambu. Paper... Caxambu, 2015a.

BRANDÃO, C. R. O que é Educação. São Paulo: Editora Brasiliense, 1981.

BRANT, Danielle. Olavo de Carvalho diz que aceitaria ser embaixador nos EUA do governo Bolsonaro, Folha de S.Paulo, [s. l.], 6 nov. 2018. Disponível em:

https://www1.folha.uol.com.br/mundo/2018/11/olavo-de-carvalho-diz-que-aceitaria-ser-embaixadornos-eua-do-governo-bolsonaro.shtml?origin=folha. Acesso em: 25 fev. 2021.

BRASIL. Decreto ${ }^{\mathbf{0}}$. 10.004, de 5 de setembro de 2019. Institui o Programa Nacional das Escolas Cívico-Militares. Disponível em: <http://www.planalto.gov.br/ccivil_03/_ato2019-

2022/2019/decreto/D10004.htm>. Acesso em: 20 set. 2019.

BRASIL. Decreto $\mathbf{n}^{\mathbf{0}} \mathbf{8 8 . 7 7 7}$, de 30 de setembro de 1983. Aprova o regulamento para as polícias militares e corpos de bombeiros militares (R-200). Disponível em: <http://www.planalto.gov.br/ccivil_03/decreto/d88777.htm>. Acesso em 28 de fev. de 2021.

BRASIL. Decreto ${ }^{\circ}$. 9.940, de 24 de julho de 2019. Altera o Decreto $n^{\circ} .88 .777$, de 30 de setembro de 1983, que aprova o Regulamento para as Polícias Militares e Corpos de Bombeiros Militares (R-200). Disponível em: <http://www.planalto.gov.br/ccivil_03/_ato2019-2022/2019/decreto/D9940.htm>. Acesso em: 28 fev. 2021.

BRASIL. Portaria $\mathbf{n}^{\circ}$ 2.015, de 20 de novembro de 2019. Regulamenta a implantação do Programa Nacional das Escolas Cívico-Militares - Pecim em 2020, para consolidar o modelo de Escola CívicoMilitar - Ecim nos estados, nos municípios e no Distrito Federal. Disponível em:

$<$ http://escolacivicomilitar.mec.gov.br/images/pdf/legislacao/portaria_2015_20112019.pdf>. Acesso em: 28 fev. 2021.

BRASIL. Projeto de Lei $\mathbf{n}^{\circ}$. 1.411, de 2015. Tipifica o crime de Assédio Ideológico e dá outras providências, alterando o Decreto-lei no ${ }^{\circ} .2 .848$, de 1940 e a Lei no .8 .069 , de 1990. Disponível em: $<$ https://www.camara.leg.br/proposicoesWeb/fichadetramitacao?idProposicao=1229808>. Acesso em: 28 fev. 2021

BRASIL. Projeto de Lei $\mathbf{n}^{\mathbf{0}}$. 193, de 2016. Inclui entre as diretrizes e bases da educação nacional, de que trata a Lei n. 9.394, de 20 de dezembro de 1996, o "Programa Escola sem Partido". Senado Federal, Brasília, DF. 04, maio, 2016.

BRASIL. Projeto de Lei $\mathbf{n}^{\circ}$. 867, de 2015. Inclui, entre as diretrizes e bases da educação nacional, o "Programa Escola sem Partido". Câmara dos Deputados, Brasília, DF. 23, março, 2015.

BRASIL. Projeto de Lei $\mathbf{n}^{\circ}$. 2401, de 2019. Dispõe sobre o exercício do direito à educação domiciliar, altera a Lei $n^{\circ}$. 8.069, de 13 de julho de 1990 - Estatuto da Criança e do Adolescente, e a Lei no. 9.394, de 20 de dezembro de 1996, que estabelece as diretrizes e bases da educação nacional. Brasília: Câmara dos Deputados, [2019]. Disponível em:

<https://www.camara.leg.br/proposicoesWeb/prop_mostrarintegra;jsessionid=FFF83CED05B04F8E67 A65024E6DE40DD.proposicoes WebExterno1?codteor=1734553\&filename $=\mathrm{PL}+2401 / 2019>$. Acesso em: 28 fev. 2021.

BRAZ, Marcelo. O golpe nas ilusões democráticas e a ascensão do conservadorismo reacionário. Serv. Soc. Soc., São Paulo, n. 128, p. 85-103, abril/2017. 
BRITTO, Tatiana Feitosa de. O que os professores (não) podem dizer? A experiência canadense e a “Escola sem Partido". Rev. Bras. Educ., Rio de Janeiro, v. 24, e240019, 2019.

BRUGNAGO, Fabrício; CHAIA, Vera. A nova polarização política nas eleições de 2014: radicalização ideológica da direita no mundo contemporâneo do Facebook. Aurora: revista de arte, mídia e política, São Paulo, v.7, n.21, p. 99-129, out.2014/jan.2015.

BUTLER, J. Problemas de gênero: feminismo e subversão da identidade. Rio de Janeiro: Civilização Brasileira, 2013.

CAFARDO, R.; JANSEN, R. Estudantes de colégios militares custam três vezes mais ao país, Estadão, [s. l.], 25 ago. 2018. Disponível em: https://politica.estadao.com.br/noticias/eleicoes,estudantesde-colegio-militar-custam-tres-vezes-mais-ao-pais,70002473230. Acesso em: 25 fev. 2021.

CARVALHO, Marcos Castro; SIVORI, Horacio Federico. Ensino religioso, gênero e sexualidade na política educacional brasileira. Cad. Pagu, Campinas, n. 50, 2017.

CARVALHO, Olavo de. A "ideologia de gênero" é uma estupidez tão monstruosa que o simples fato de alguém aceitá-la como hipótese para discussão já revela uma total inépcia intelectual... Richmond (VA), 27 de fev. de 2016. Facebook: @carvalho.olavo. Disponível em:

<https://www.facebook.com/carvalho.olavo/posts/602122786606466/>. Acesso em 28 fev. 2021.

CARVALHO, Olavo de. O mínimo que você precisa saber para não ser um idiota. 1. ed. Rio de Janeiro: Record, 2013.

CARVALHO, Olavo de. Os novos demiurgos (2). Diário do Comércio, São Paulo, 23 de out. de 2009. Disponível em: <https://olavodecarvalho.org/educacao-ou-deformacao/>. Acesso em 28 fev. 2021.

CARVALHO, Olavo de.; ALVES, Alaôr Caffé. Marxismo, direito e sociedade. São Paulo: Faculdade de Direito da Universidade de São Paulo - USP, 2003.

CARVALHO, Olavo de; DUGIN, Alexandre. Os EUA e a Nova Ordem Mundial. Tradução de Giuliano Moraes. Campinas, SP: VIDE Editorial, 2012.

CHAMPLIN, R. N.; BENTES, J. M. Enciclopédia de Bíblia, Teologia e Filosofia. 1. ed. São Paulo: Editora Candeia, 1991.

CHAVES, E. O. C. Tecnologia e Educação: o futuro da escola na sociedade da informação. Campinas: Mindware, 1998.

COSTA, Iná Camargo. Dialética do marxismo cultural. São Paulo: Expressão Popular, 2020.

CUNHA, Luiz Antônio. O projeto reacionário de educação. Produção Digital Independente (Homepage), 2016. Disponível em: < http://www.luizantoniocunha.pro.br/uploads/independente/1EduReacionaria.pdf $>$. Acesso em: 05 jan. 2021.

DA NOVA, L.; DE LIMA BONET'TI, A. Escolas Cívico-militares: uma nova face das Escolas sem Partido?. Anais do Salão Internacional de Ensino, Pesquisa e Extensão, v. 11, n. 2, 28 ago. 2020.

DUARTE, Letícia. “Destruição é a agenda do Tradicionalismo”, a ideologia por trás de Bolsonaro e Trump. El País, [s. l.], 12 dez. 2020. Disponível em: <https://brasil.elpais.com/brasil/2020-1212/benjamin-teitelbaum-destruicao-e-a-agenda-do-tradicionalismo-a-ideologia-por-tras-de-bolsonaro-etrump.html>. Acesso em: 23 fev. 2021.

ENSINO, EDUCAÇÃO E DOUTRINAÇÃO. ESCOLASEMPARTIDO.ORG. Disponível em: <http://www.escolasempartido.org/artigos-top/554-ensino-educacao-e-doutrinacao >. Acesso em: 15 jun. 2019

ESCOLA SEM PARTIDO. 2017. Disponível em: Disponível em: < http://escolasempartido.org>. Acesso em: 8 abr. 2017.

ESCOLA SEM PARTIDO. ESCOLASEMPARTIDO.ORG. Disponível em: <http://www.escolasempartido.org/>. Acesso em: 15 jun. 2019. 
FALAK, Marcelo. Bolsonaro, un líder construido en pos de un nuevo proyecto de poder militar, Ámbito, [s. l.], 6 out. 2018, Disponível em: <https://www.ambito.com/mundo/bolsonaro-un-liderconstruido-pos-un-nuevo-proyecto-poder-militar-n4035789>. Acesso em: 27 fev. 2021.

FELLET, João. Monarquistas ocupam cargos em Brasília e reabilitam grupo católico ultraconservador. BBC Brasil, [s. l.], 4 abr. 2019. Disponível em: <https://www.bbc.com/portuguese/brasil-47728267>. Acesso em: 23 fev. 2021.

FERREIRA, Gabriela Nunes; BOTELHO, André. Revendo o pensamento conservador. In: FERREIRA, Gabriela Nunes; BOTELHO, André (Orgs.). Revisão do pensamento conservador: ideias e política no Brasil. São Paulo: Hucitec, 2010. (Col. Pensamento Político-Social, v. 3.).

FILHO, João. $\mathbf{O}$ casamento entre a extrema direita e o movimento antivacina é um perigo para o mundo. The Intercept Brasil, [s. l.], 14 jul. 2019. Disponível em:

<https://theintercept.com/2019/07/14/movimento-antivacina-extrema-direita-trump-bolsonaro/>. Acesso em: 23 fev. 2021.

FLICK, U. Introdução à pesquisa qualitativa. $3^{\mathrm{a}}$ ed. Porto Alegre, Artmed, 2009.

FOLHA informativa - Gênero. OPAS Brasil, [s. l.], 08 2015. Disponível em:

$<$ https://www.paho.org/bra/index.php?option=com_content\&view =article\&id=5668:folha-informativagenero\&Itemid=820>. Acesso em: 25 fev. 2021.

FREIRE, Paulo. Pedagogia da autonomia: saberes necessários à prática educativa. São Paulo: Paz e Terra, 1996.

GÓES, Andrei Cavalcanti Lopes; SOUZA, Marcus Vinicius da Silva Pereira de. O "homeschooling" e as novas formas de educar no Brasil: um diálogo entre o direito e a pedagogia. Revista Ciências Jurídicas e Sociais Aplicadas, Universidade de Iguaçi (UNIG), v. 2, nº. 1, p. 146-150, jan/jun 2019.

GONÇALVES, Jacqueline da Silva. Pedagogia da educação infantil: avanços, desafios e tensões. 107 f. Dissertação (Mestrado) - Universidade do Estado de Minas Gerais - Faculdade de Educação Programa de Pós Graduação em Educação, 2011.

GONÇALVES, Leandro Pereira; CALDEIRA NETO, Odilon. O fascismo em camisas verdes: do integralismo ao neointegralismo. 1. ed. Rio de Janeiro: FGV Editora, 2020.

HALIMI, Serge. Un débat intellectuel en trompe-l'oil. Le Monde Diplomatique, Paris, janeiro de 2003, Archives, p. 3.

JUNQUEIRA, R. D. "Ideologia de gênero": a gênese de uma categoria política reacionária-ou: a promoção dos direitos humanos se tornou uma "ameaça à família natural”. In.: RIBEIRO, P. R. C.; MAGALHÃES, J.C. Debates contemporâneos sobre educação para a sexualidade. Rio Grande: Ed. da FURG, p. 25-52, 2017.

KIRK, Russel. A política da prudência. Tradução Gustavo Santos, Márcia Xavier de Brito. São Paulo: Realizações, 2014. (Col. Abertura Cultural.).

LIMA, Iana Gomes de; HYPOLITO, Álvaro Moreira. Escola sem Partido: análise de uma rede conservadora na educação. Práxis Educativa, Ponta Grossa, v. 15, e2015290, p. 1-17, 2020.

MACEDO, Elisabete. As demandas conservadoras do Movimento Escola sem Partido e a Base Nacional Curricular Comum. Educ. Soc., Campinas, v. 38, nº. 139, p.507-524, abr.-jun., 2017.

MAIA, Marcos Felipe Gonçalves; ROCHA, Damião. Ideologia de gênero: tensões e desdobramentos na educação. Revista Contemporânea de Educação, vol. 12, n. 25, set/dez de 2017.

MARANHÃO, Eduardo Meinberg de Albuquerque; COELHO, Fernanda Marina Feitosa; DIAS, Tainah Biela. "Fake news acima de tudo, fake news acima de todos": Bolsonaro e o "kit gay", "ideologia de gênero" e fim da "família tradicional". Revista Eletrônica Correlatio, v. 17, n. 2, dez/2018.

MARTIN, André Antunes. Sobre os dias atuais: neoconservadorismo, escolas cívicomilitares e o simulacro da gestão democrática. Revista Brasileira de Política e Administração da Educação, [s. 1.], v. 35, ed. 3, p. 689-699, 2019. 
MARTINS, Fabio Henrique Araújo. Sobre a violência no brasil: questões e problemas para o direito e a psicologia. 2020, 178 f. Tese de doutorado - Universidade Estadual Paulista, Assis, 2020.

NACIF, Paulo Gabriel Soledade; FILHO, Penildon Silva. A educação brasileira na mira do obscurantismo e Estado mínimo. In: Leite, A. Z. et al. (Orgs). Brasil: incertezas e submissão?. 1. ed. São Paulo: Fundação Perseu Abramo, 2019.

NATIVIDADE, Marcelo Tavares; OLIVEIRA, Leandro de. (2009), "Sexualidades ameaçadoras: religião e homofobia (s) em discursos evangélicos conservadores". Sexualid, Salud y Sociedad: Revista Latino-americana, vol. II: 121-161.

NEHER, Clarissa. "Nazismo de esquerda": o absurdo virou discurso oficial em Brasília. DW Brasil, [s. l.], 28 mar. 2019. Disponível em: <https://www.dw.com/pt-br/nazismo-de-esquerda-o-absurdo-viroudiscurso-oficial-em-bras\%C3\%ADlia/a-48060399>. Acesso em: 23 fev. 2021.

OAKESHOTT, Michael. Ser conservador. Tradução Rafael Borges. Gabinete de Estudos Gonçalo Begonha, 2014.

OLIVEIRA, R. D. S.; BATALHA, E. O. M. O mito da "ideologia de gênero" nas escolas: uma análise sociológica da tentativa conservadora de silenciar o pensamento crítico. Inter-legere (UFRN), v. 1, p. 44-59, 2017.

PETRARCA, Fernanda Rios. Uma Janela no Tempo: a ascensão do Bolsonarismo no Brasil. Revista Tomo, v. 38, p. 339-371, 2021.

PRINCÍPIOS de Yogyakarta: princípios sobre a aplicação da legislação internacional de direitos humanos em relação à orientação sexual e identidade de gênero. Tradução Jones de Freitas. jul. 2007. Disponível em: <http://www.dhnet.org.br/direitos/sos/gays/principios_de_yogyakarta.pdf>. Acesso em: 26 jan. 2021.

RAMOS, A.; FARIA, P. M.; FARIA, Á. Revisão sistemática de literatura: contributo para a inovação na investigação em Ciências da Educação. Rev. Diálogo Educ, Curitiba, v. 14, n. 41, p. 17-36, 2014.

SEPULVEDA, José Antonio Miranda; SEPULVEDA, Denize. O pensamento conservador e sua relação com práticas discriminatórias na educação: a importância da laicidade. Revista Teias, [S.l.], v. 17, n. 47, p. 141-154, ago. 2016.

SILVA, I. P.; MERCADO, L. P. Levantamento dos temas TIC e EAD na biblioteca virtual Educ@. Cadernos de Pesquisa, v. 45, n. 158, p. 970-988, 2015.

SILVA, Ivanderson Pereira da. Em busca de significados para a expressão "Ideologia de Gênero". Educ. Rev. [online]. vol. 34, EPUB, dezembro de 2019.

SILVA, Michel Goulart da. O escola sem partido como expressão do ideário militar. Germinal: Marxismo e Educação em Debate, Salvador, v. 10, n. 3, p. 169-175, dez. 2018.

SILVA, Michel Goulart da. Reflexões sobre o "marxismo cultural”. Boletim de Conjuntura (BOCA), Boa Vista, v. 1, n. 3, p. 77-82, mar. 2020.

SILVA, Tomaz Tadeu da. Documentos de Identidade: Uma Introdução às Teorias de Currículo. $3^{\circ}$. Edição. Editora Autêntica. 2010.

SIMÕES, C. A. Análise da medida provisória sobre alterações curriculares do ensino médio na LDB,. [s. l.], set/2016. Disponível em:

$<$ https://avaliacaoeducacional.files.wordpress.com/2016/09/artexes_analise-da-mp-do-ensino-medio. pdf>. Acesso em: 12 jan. 2021.

STF, Supremo Tribunal Federal. STF nega recurso que pedia reconhecimento de direito a ensino domiciliar. Brasilia, setembro, 2018. Disponível em:

<http://www.stf.jus.br/portal/cms/verNoticiaDetalhe.asp?idConteudo=389496>. Acesso em: 12 jan. 2021.

TSE. Brasil acima de tudo, Deus acima de todos. 2018. Disponível em: < http://www.tse.jus.br/eleicoes/eleicoes-2018/propostas-de-candidatos> . Acesso em: 12 de set. 2018. 
URIBE, Gustavo; LADEIRA, Pedro; NUNES, Wálter. Apoiadores de Bolsonaro fazem ato próintervenção, e opositores usam cruzes para criticar governo. Folha de S.Paulo, [s. l.], 28 jun. 2020. Disponível em: <https://www1.folha.uol.com.br/poder/2020/06/apoiadores-de-bolsonaro-fazem-atopro-intervencao-e-opositores-usam-cruzes-para-criticar-governo.shtml>. Acesso em: 23 fev. 2021.

VEIGA-NETO, A. Foucault e a Educação. Belo Horizonte: Ed. Autêntica, 2003.

VEJA a biografia de Jair Bolsonaro, presidente eleito do Brasil. Folha de S.Paulo, [s. l.], 28 out. 2018. Disponível em: <https://www1.folha.uol.com.br/poder/2018/10/veja-a-biografia-de-jair-bolsonaropresidente-eleito-do-brasil.shtml?origin=folha\#>. Acesso em: 25 fev. 2021.

VELHO, B. M. Percepções de um contrato racial na trajetória educacional dos negros no Brasil: estudo a partir da representatividade dos negros no município de Concórdia, SC. Dissertação (Mestrado em Educação) - Universidade Federal da Fronteira Sul. Chapecó, p. 153. 2020.

\begin{abstract}
Notas
${ }^{1}$ Possui graduação em Pedagogia pela Universidade do Estado de Minas Gerais. Currículo Lattes: http://lattes.cnpq.br/2959167370445358. Orcid: http://orcid.org/0000-0003-2376-4858. E-mail: lucasccosta@live.com.

${ }^{2}$ Graduada em Pedagogia pela Universidade do Estado de Minas Gerais. Pós-graduanda em Educação Especial, Inclusiva e Libras pela faculdade Estratego. Currículo Lattes: http://lattes.cnpq.br/7023089088083877. Orcid: https://orcid.org/0000-0002-8125-
\end{abstract} 4867.E-mail: caroline.duailibi17@gmail.com

${ }^{3}$ Graduada em Pedagogia pela Universidade do Estado em Minas Gerais. Currículo Lattes: http://lattes.cnpq.br/5371405329687404. Orcid: https://orcid.org/0000-0003-3533-7378. E-mail: francisdavila@,outlook.com.

${ }^{4}$ Graduada em Pedagogia pela Universidade do Estado de Minas Gerais. Currículo Lattes: http://lattes.cnpq.br/7023089088083877 . Orcid: https://orcid.org/0000-0003-3533-7378 . E-mail: deborah.diegues@gmail.com .

5 Comportamentos dissonantes da heterossexualidade costumam ser objeto de oposição por parte das correntes religiosas hegemônicas e movimentos conservadores no Brasil. Um exemplo muito expressivo é a histórica obstrução dos direitos civis das populações LGBT pela dita bancada evangélica. (NATIVIDADE; OLIVEIRA, 2009).

${ }^{6} \mathrm{Um}$ pequeno grupo de apoiadores do presidente Jair Bolsonaro realizou no dia 28 de junho de 2020 , em Brasília, um protesto em que pediu intervenção militar com Bolsonaro no poder. $\mathrm{O}$ ato ocorreu em frente ao Quartel General do Exército. Outras manifestações, antes desta específica, já haviam ocorrido também, principalmente em redes sociais. (URIBE et al., 2020).

7 Uma reportagem da BBC Brasil revelou o avanço do movimento monarquista sobre o Congresso e o governo Bolsonaro. (FELLET, 2019).

8 O Integralismo - versão brasileira do fascismo italiano dos anos 1930 - permanece vivo e presente no cenário sociopolítico brasileiro e o presidente Jair Bolsonaro, "uma das figuras políticas recentes mais próximas ao fascismo histórico", foi eleito com o apoio de integrantes deste movimento. (GONÇALVES; NETO, 2020).

${ }_{9}^{9}$ Em estudo realizado pela pesquisadora Adriana Dias, aproximadamente cerca de 150 mil brasileiros visitam mensalmente mais de cem páginas com conteúdos nazistas. Segundo Dias, desse total, 15 mil são líderes e coordenam as incitações de ódio na internet. Os grupos "físicos" seriam de pequeno porte e, segundo a autora, teriam entre 15 a 20 pessoas. (ANDRADE, 2013).

${ }^{10}$ Dante Mantovani, nomeado presidente da Funarte por Jair Bolsonaro, por exemplo, em muitos de seus vídeos afirma que a Terra é plana. $(\mathrm{G} 1,2019)$.

${ }^{11} \mathrm{O}$ movimento antivacina não é recente, mas ganhou visibilidade assim como os outros movimentos reacionários: através da internet. A eficácia das vacinas, para esses, deixou de ser um fato e passou a ser uma questão de opinião. Assim como a crença na Terra plana, o movimento antivacina tem encontrado guarida na extrema-direita mundial. (FILHO, 2019).

12 "Dom" Bertrand, trineto de Dom Pedro II e príncipe imperial brasileiro que lidera um movimento que pretende reinstaurar a monarquia no país, é autor do livro "Psicose Ambientalista - Os Bastidores do Ecoterrorismo para implantar uma Religião Ecológica Igualitária e Anticristã".

${ }^{13} \mathrm{O}$ escritor Olavo de Carvalho atribuiu a ascensão do nazismo e a eclosão da $2^{\mathrm{a}}$ Guerra Mundial a um plano idealizado com antecedência pelo ditador Josef Stálin. (CARVALHO; ALVES, 2003).

${ }^{14} \mathrm{O}$ atual ministro das Relações Exteriores, Ernesto Araújo, aderiu à tese de que o nazismo foi um movimento de esquerda. A declaração foi dada em uma longa entrevista a um canal simpático à extrema direita no Youtube, mas repete um discurso que esteve em alta nas mídias sociais brasileiras durante as eleições de 2018. (NEHER, 2019).

$15 \mathrm{O}$ presidente da Fundação Palmares (instituição ligada à Secretaria Especial de Cultura), Sergio Nascimento de Camargo, já afirmou em suas redes sociais que o Brasil tem um "racismo Nutella" e que a escravidão foi "benéfica para os afrodescendentes". (VELHO, 2020). 
${ }^{16}$ Segundo Benjamin R. Teitelbaum, esse pensamento é típico de um tradicionalismo, em que é acreditado "que a humanidade está ao fim de um longo ciclo de declínio e que vai ser concluído com destruição e renascimento". (DUARTE, 2020). Assim, Carvalho se posiciona como crítico do kantianismo, do hegelianismo, do marxismo, do positivismo, do pragmatismo, do nietzscheanismo, da psicanálise, da filosofia analítica, do existencialismo, do desconstrucionismo, da teologia da libertação, do relativismo moral, cultural e ético, dentre outras correntes filosóficas e intelectuais que apregoam ideias que se posicionam, em sua maioria, contrárias ao medievalismo.

${ }^{17}$ Bolsonaro tentou ser candidato à presidência em 2014 pelo seu partido na época, o PP (Partido Progressista). Chegou a apresentar uma carta de intenção para ganhar a nomeação, mas acabou sendo vetado. Por fim, o partido declarou apoio à reeleição de Dilma Rousseff, o que rendeu protestos por parte de Bolsonaro e alguns dos seus seguidores abrigados na legenda. (BARRETTO, 2014).

${ }_{18}$ Por mais que alguns analistas afirmem que Bolsonaro, após a consolidação de seu governo, já não possui mais dependência de Olavo de Carvalho e seus seguidores. Outro fator que é importante ressaltar: o governo Bolsonaro não é, necessariamente, bolsolavista. Existem vários movimentos e setores, segundo analistas, que disputam poder dentro do núcleo que comanda o país. Podemos identificar pelo menos outras quatro forças além do bolsolavismo, que é conhecido como ala ideológica do governo: os militares, que possuem diversos cargos estratégicos em ministérios; os evangélicos, que hoje controlam os ministérios da Educação e da Mulher, Família e dos Direitos Humanos e ditam muitas pautas no governo; a ala econômica, chefiada pelo ministro da economia Paulo Guedes; e uma parte do que se conhece como centrão fisiológico. Essas forças também não são declaradamente inimigas, apenas realizando disputas em alguns momentos, o que também não as inibe de fazer alguns acordos ou uniões táticas e programáticas em outros.

19 Ao falar de movimentos assumidamente ideológicos, estamos nos referindo a movimentos políticos organizados de todos os campos do espectro político, conservadores e progressistas, democráticos e autoritários, de esquerda e de direita. Apesar disso, alguns desses movimentos assumidamente ideológicos se apresentam como neutros, sem qualquer tipo de ideologia. De acordo com o que apresentaremos adiante neste trabalho, não há nada nas pesquisas em ciências humanas, o que inclui a política, que seja neutro. Mesmo assim, não é raro tais movimentos se declararem dessa forma. Os exemplos clássicos são as correntes liberais tradicionais e as correntes conservadoras de influência britânica. (OAKESHOTT, 2014; KIRK, 2014). 